\title{
A Vast Array of Beauty: The Accomplishments of the Father of American Ornamental Breeding, Luther Burbank
}

\author{
Neil O. Anderson ${ }^{1,3}$ \\ Department of Horticultural Science, University of Minnesota, 1970 Folwell Avenue, St. Paul, MN 55108 \\ Richard T. Olsen ${ }^{2}$ \\ U.S. Department of Agriculture/Agricultural Research Service U.S. National Arboretum, Floral and Nursery Plants \\ Research Unit, 10300 Baltimore Avenue, Beltsville, MD 20705
} Additional index words. convenience, exclusivity, flower color, flower power, flower surround, fragrance, intergeneric hybridization,
interspecific hybridization, mass breeding, shasta daisy, spineless cacti, sterility

\begin{abstract}
Luther Burbank (1849-1926) was a prolific ornamental plant breeder, who worked with 91 genera of ornamentals, from Abutilon to Zinnia, and released nearly 1000 cultivars to the industry. His innovative work included both herbaceous and woody plant materials as well as ornamental vegetables such as corn, tomatoes, and spineless cacti. His most popular ornamental release, the shasta daisy hybrids - first released in 1901, is still on the global market. This article focuses on Luther Burbank's breeding techniques with ornamental plants and how both the germplasms that he developed and his methodologies used permeate modern flower breeding. Genera with the highest number of cultivars bred and released by Burbank include Amaryllis, Hippeastrum, and Crinum followed by Lilium, Hemerocallis, Watsonia, Papaver, Gladiolus, Dahlia, and Rosa. With Lilium, he pioneered breeding the North American native lily species, particularly those from the Pacific coastal region, producing the eponymous Lilium $\times$ burbankii. Burbank's breeding enterprise was designed to be selfsustaining based on profits from selling the entire product line of a new cultivar or crop only to wholesale firms, who then held exclusives for propagation and selling, although financial hardships necessitated selling retail occasionally. Entire lots of selected seedlings were sold to the highest bidder with Burbank setting the price in his annual catalogs such as the Burbank Hybrid Lilies lot for U.S. \$250,000 or some of the "very handsome, hardy ones" for U.S. \$250 to U.S. \$10,000 each. Other flower cultivars also commanded high prices such as seedling Giant Amaryllis that sold for U.S. \$1.55/bulb in 1909. Cacti were another area of emphasis (he released more than 63 cultivars) from the spineless fruiting and forage types (Opuntia ficus-indica, O. tuna, O. vulgaris) to flowering ornamentals such as $O$. basilaris, Cereus chilensis, and Echinopsis mulleri. Interest in cacti during 1909-15 rivaled the Dutch Tulip mania with exorbitant fees for a single "slab" of a cultivar, speculative investments, controversy with noted cacti specialists (particularly David Griffiths), and lawsuits by The Burbank Company. Although most cultivars have been lost, Burbank's reputation as the Father of American Ornamental Breeding remains admirable from critics and devotees alike.
\end{abstract}

Luther Burbank passionately bred all commodities of horticultural plants, particularly ornamentals (herbaceous and woody flowers, trees, shrubs), on his own properties, first at his 4-acre home and nursery in Santa Rosa, CA, but later, and primarily, on his own Research Station known as Luther Burbank's Gold Ridge View Experiment Farm located at 7781 Bodega Avenue, Sebastopol, CA (Fig. 1A; Dreyer, 1993; Smith, 2009; Williams, 1915). Perhaps best known for his work on small fruits and vegetables, ornamentals (herbaceous and woody flowers, trees, shrubs) did not escape

Received for publication 15 July 2014. Accepted for publication 12 Aug. 2014.

This paper was part of the workshop "Contributions of Luther Burbank: Plant Breeding Artist and Legend" held 22 July 2013 at the ASHS Conference, Palm Desert, CA, and sponsored by the ASHS History of Horticultural Science Working Group.

This research has been supported in whole or in part by the Minnesota Agricultural Experiment Station.

The mention of trade names or commercial products in this article is solely for the purpose of providing specific information and does not imply recommendations or endorsement by the U.S. Department of Agriculture (USDA). The USDA is an equal opportunity employer.

${ }^{1}$ Professor.

${ }^{2}$ Research Geneticist.

${ }^{3}$ To whom reprint requests should be addressed; e-mail ander044@umn.edu. the work of the "Plant Wizard of Santa Rosa." The Gold Ridge View Experiment Farm was an efficient, 16- to 18-acre site (Bush, 1982; Hall, 1939) with continuous rotations of new generational hybrids growing in successive plots in the fields, coldframes/hot beds, or glasshouses. It was common to find rows of mature selections of flowers and other ornamentals growing alongside plums or apples. Yearly bonfires in the fall were commonly used to destroy all unwanted (rogued) breeding stock and grow-outs.

As a result of his prominence in the growing circle of horticultural plant breeders, Burbank had numerous volunteer plant collectors across the globe that shipped him enormous quantities of germplasm as well as direct access to the USDA Bureau of Plant Industry germplasm introductions by David Fairchild. This afforded Burbank the opportunity to focus on developing his methodologies of breeding, selection, and commercialization of floral products, which singularly have surpassed the efforts of any individual flower breeder to the present day. For example, the purchase of many elite breeding lines, germplasm, and market-ready cultivars after Burbank's death in 1926 allowed Stark Brothers Nurseries to offer a wide array of ornamental products to the market (Fig. 1C).

The objectives of this article focus on the art and science of Luther Burbank's techniques with ornamental plants and how both the germplasm that he developed and his methodologies used thereon still permeate modern flower breeding. Rather than focusing on every floral product that he bred (Table 1; covered quite extensively by Howard, 1945), a few exemplary ones are used to illustrate the methodological approaches used by Burbank to achieve his world status as the Father of American Ornamental Breeding.

\section{BREEDING AND MARKETING METHODOLOGY}

Luther had very little formal education, which ended at the age of 19 years as a result of his Father's untimely death in 1868 (Howard, 1945). Two years later he became a Market Gardener, where he attempted his first crosses with vegetables to create earlier types (Howard, 1945). This was not successful because he used noninbred parents, which meant that the $F_{1}$ hybrids did not possess hybrid vigor or heterosis. Later, on reading Darwin's "Variation of Animals and Plants Under Domestication" (Darwin, 1868), he learned about backcrossing and breeding for multiple generations to obtain segregants with variation. After immigrating to California in 1875 , he worked for less than 1 year in a nursery (Petaluma, CA) collecting bulbs and openpollinated (OP) seeds of California wildflowers, which he sold to seedsmen in the eastern United States (Howard, 1945). He started his first nursery in Santa Rosa, CA, in 1877 , but soon focused strictly on highly 

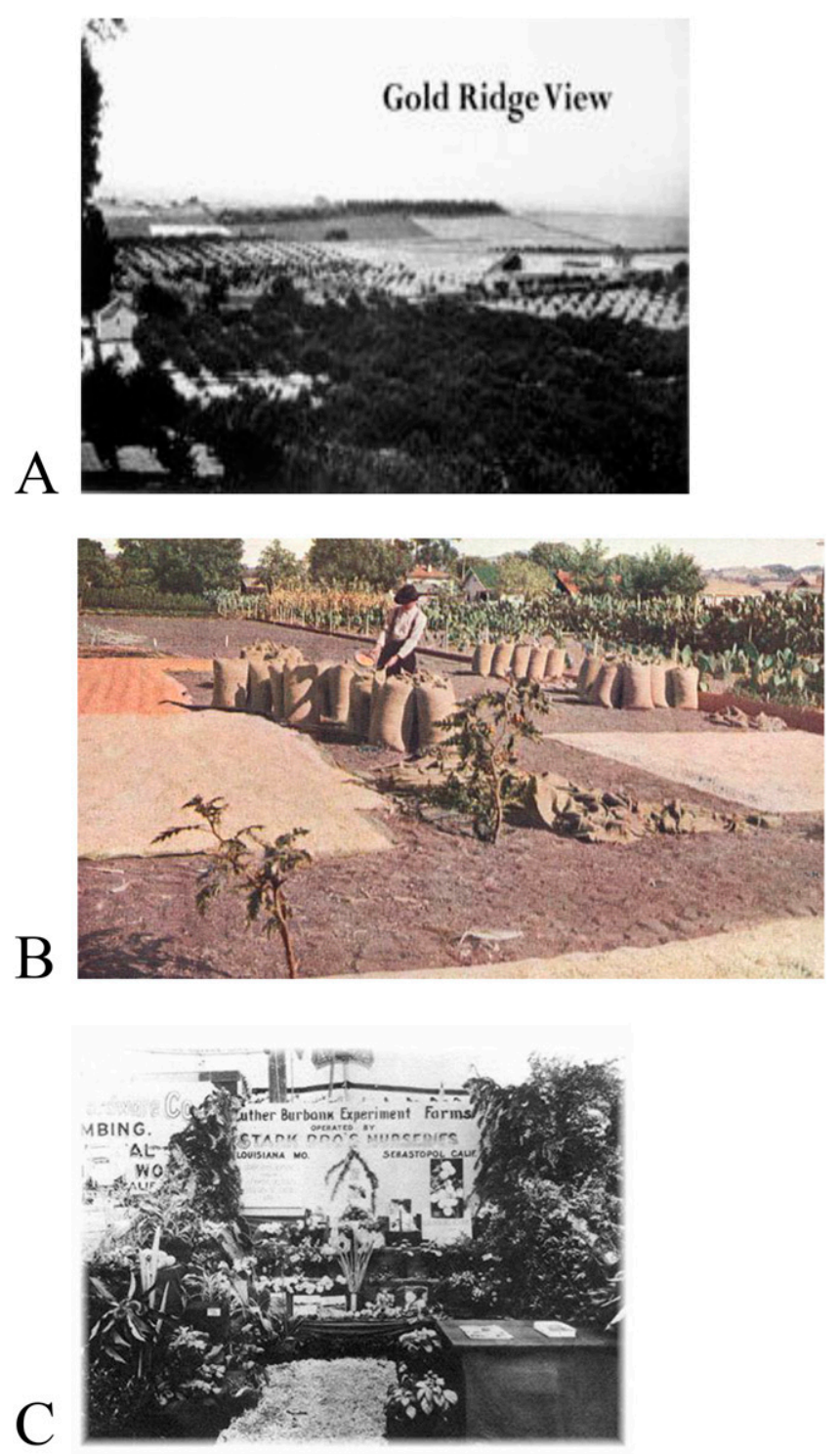

Fig. 1. Operational views of the Burbank Experiment Station: (A) The Luther Burbank's Gold Ridge View Experiment Farm, Sebastopol, CA, at the hiatus of Burbank's breeding endeavors; (B) winnowing and bagging seed from the season's collection - large quantities were often open-pollinated; (C) a display of the Luther Burbank Experiment Forms of ornamental plants by Stark Brothers' Nurseries, which purchased most of the remaining stock after Burbank's death (Smith, 2009).

valued fruit and flower "novelties" sourced from grow-outs of germplasm collected in the wild, "chance seedlings," exotic imports, or limited breeding (Howard, 1945). This unique process helped Burbank develop his "eye" for variation and mutations, the foundation for his success as well as for today's ornamental industry. As Claude Hope, the famous $\mathrm{F}_{1}$ hybrid Impatiens and Petunia breeder (Martinez, 1992) noted years later, "A successful breeder has to be a good observer" (Pollan, 2001). The ability to identify and select variants in large populations is an art still used by modern public and private sector flower breeders.

Exclusivity. After Burbank purchased The Gold Ridge Experiment Farm, undoubtedly this along with the Santa Rosa farm became the largest such private sector breeding station in the world, both in its timeframe of
The business was meant to be a selfsustaining, profitable, and non-conventional nursery selling the entire product line of a new cultivar or crop only to wholesale firms instead of selling as retail (Howard, 1945). Several large firms participated in this endeavor, both nationally (Stark Brothers Nurseries, John Lewis Childs, W.A. Atlee Burpee Co.) and internationally (J.M. Rutland, Victoria, Australia) (Howard, 1945; Smith, 2009). The highest bidder earned exclusive rights as a propagator, distributor, or retailer to sell the products on the market.

Speculation and selling to the highest bidder were common occurrences with Luther Burbank's floral products. Speculation was fueled by Burbank's own exaggerated claims for his new plant improvements as well as those of the wholesalers who sold his introductions to the general public. Through Burbank's annual catalog, new products were hawked with prices set by Burbank. For example, for his entire line of hybrid lilies (L. $\times$ burbankii), the price was U.S. \$250,000 or for individual "very handsome, hardy ones" U.S. $\$ 250$ to U.S. $\$ 10,000$ each (Burbank, 1914-15; Howard, 1945). Other flower cultivars also commanded high prices such as the seedling Giant amaryllis that sold for U.S. \$1.55/bulb in 1909 (Burbank, 1909). Interest in cacti-particularly spineless onesduring 1909-15, rivaled the Dutch Tulip mania with exorbitant fees for a single "slab" of a cultivar, speculative investments, controversy with noted cacti specialists (particularly David Griffiths; Smith, 2009), and lawsuits by The Burbank Company. Thus, Burbank created the legacy of "exclusivity" in the flower worldstill a common factor for all breeder, producer, and distributor companies driving limited supply and increased demand of novelty items (Anderson, 2006; Drew et al., 2010).

Because flowers and other ornamental crops are economically classed as nonessential food crops and are risky during economic downturns (Drew et al., 2010), many of Burbank's products did not sell in any given year (Howard, 1945). This leftover stock (seeds or vegetative plant material) had to be held over for another year's sales, prompting Burbank to continue to sell at the retail level. This practice ended when the Luther Burbank Company was founded in 1912 as a distributor firm, which had exclusivity to all products Luther Burbank bred (Howard, 1945). The Luther Burbank Company, however, was short-lived and in 1916 it went bankrupt-attributable in large part to the cactus debacle - and Burbank regained the business. Subsequently, Burbank focused on being a breeder-producer company within the horticultural distribution chain (Drew et al., 2010), selling only seeds until his death in 1926.

Insourcing. Because most of Burbank's competitors could not offer one or more new products each year to their customers, his market share increased as a result of the widening germplasm base used to select unusual mutants (Howard, 1945). Insourcing of germplasm on a global scale continued thereafter, allowing 
Table 1. A vast array of beauty: ornamental flower crops from Abutilon to Zinnia (common, scientific, and cultivar names) bred by Luther Burbank, year introduced, and origin/salient features (Burbank, 1914-15; Howard, 1945). ${ }^{\mathrm{z}}$

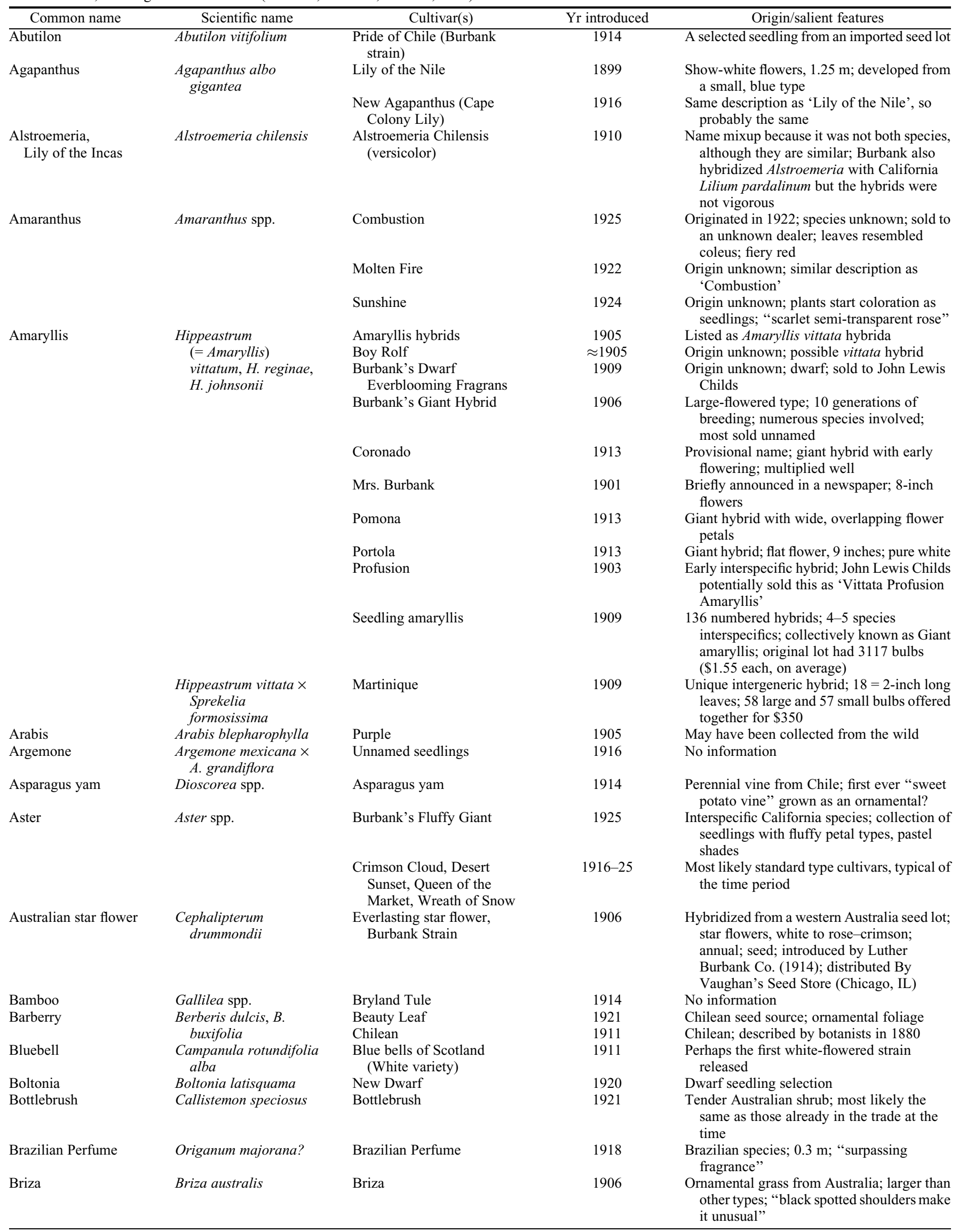

(Continued on next page) 
Table 1. (Continued) A vast array of beauty: ornamental flower crops from Abutilon to Zinnia (common, scientific, and cultivar names) bred by Luther Burbank, year introduced, and origin/salient features (Burbank, 1914-15; Howard, 1945). ${ }^{\mathrm{z}}$

\begin{tabular}{|c|c|c|c|c|}
\hline Common name & Scientific name & Cultivar(s) & Yr introduced & Origin/salient features \\
\hline Bulrush & Scirpus spp. & Flowering Bulrush & 1918 & $\begin{array}{l}\text { Species unknown; pink flowers in early } \\
\text { spring; "curious... plant from Chile" }\end{array}$ \\
\hline \multirow[t]{30}{*}{$\begin{array}{l}\text { Cactus, "spineless" } \\
\text { forage types }\end{array}$} & Opuntia spp. & Actual & $1907 ?$ & $\begin{array}{l}\text { Hybrid from the cross: 'Anacantha' } \times \\
\text { 'Smith' }\end{array}$ \\
\hline & & Anacantha & 1907 & $\begin{array}{l}\text { Original stock source (David Fairchild); } \\
\text { nearly devoid of spines }\end{array}$ \\
\hline & & Banana & $?$ & OP seedling \\
\hline & & Blanco & 1907 & $\begin{array}{l}\text { Indian-fig class; Walter Bryant (source); } \\
\text { known as 'White Cactus' }\end{array}$ \\
\hline & & Burbank Standard & 1911 & From "selective breeding" \\
\hline & & Competent & 1911 & $\begin{array}{l}\mathrm{F}_{2} \text { ?; smooth slab seedling; nearly free of } \\
\quad \text { spines; } 24 \text { to } 36 \text { inches } \times 6 \text { to } 8 \text {-inch slabs }\end{array}$ \\
\hline & & El Dorado & $?$ & OP seedling \\
\hline & & Feeder & 1916 & Compact, glossy slabs; 10 inches $\times 8$ inches \\
\hline & & Fresno & 1907 & $\begin{array}{l}\text { Indian-fig class; distributed by American } \\
\text { Cactus Farming Co. }\end{array}$ \\
\hline & & Hemet & 1909 & $\begin{array}{l}\text { Tapuna class ("tunas"); smooth with "pearly } \\
\text { white" pads' hardy }\end{array}$ \\
\hline & & Marin & 1907 & $\begin{array}{l}\text { "Absolutely without spines or bristles"; } \\
\text { smaller plants; may have been introduced } \\
\text { as 'Marine' by Don Francisco de Paula } \\
\text { Marin in } 1791\end{array}$ \\
\hline & & Melrose & 1909 & Tapuna class; smooth; strong grower \\
\hline & & Model & 1912 & Seedling from 'Smith'; no thorns \\
\hline & & Opaline & 1911 & Tapuna; large fruit \\
\hline & & Pyramid & 1909 & $\begin{array}{l}\text { Indian fig class; upright growth; one of the } \\
\text { best for poultry and livestock }\end{array}$ \\
\hline & & Robusta & 1911 & $\begin{array}{l}\text { Hybrid of Burbank; pale green slabs (2-5 lbs. } \\
\text { each) }\end{array}$ \\
\hline & & Rosamel & 1915 & Little known; hardy \\
\hline & & Santa Rosa & 1907 & $\begin{array}{l}\text { Indian-fig; Burbank's best and highest priced } \\
\text { cactus; distributed by American Cactus } \\
\text { Farming Co. }\end{array}$ \\
\hline & & Signal & 1911 & Hybrid; 4 feet in length; 10 to $20 \mathrm{lbs}$./slab \\
\hline & & Smith & 1907 & $\begin{array}{l}\text { Collected in north Africa; named after E.E. } \\
\text { Smith }\end{array}$ \\
\hline & & Solano & 1909 & Indian fig; compact, weeping habit \\
\hline & & Sonoma & 1907 & $\begin{array}{l}\text { Pale yellow; } 20 \text { inches } \times 10 \text { inches; exclusive } \\
\text { rights for the southern hemisphere sold to } \\
\text { Mr. Rutland (Melbourne, Australia) }\end{array}$ \\
\hline & & Special & 1911 & Tapuna; silvery slabs; truly spineless \\
\hline & & Texas & 1925 & $\begin{array}{l}\text { Developed from a Texas type; } 10 \text { inches } \times \\
6 \text { inches }\end{array}$ \\
\hline & & Titania & 1911 & $\begin{array}{l}\text { Light grass green color; } 36 \text { to } 48 \text { inches } \times 1.5 \\
\text { to } 3 \text { inches }\end{array}$ \\
\hline & & Trailing & 1907 & $\begin{array}{l}\text { Small, spreading plant; glossy green; } \\
\text { occasional long spine }\end{array}$ \\
\hline & & Vertex & 1911 & Hybrid; tree-like, bluish green \\
\hline & & White Fruit & ? & Parent of OP 'Banana' and 'El Dorado' \\
\hline & & Wooly & 1911 & Wooly leaves but nearly spineless \\
\hline & & Zalisco & 1912 & Smith seedling; similar to 'Model' \\
\hline
\end{tabular}


Table 1. (Continued) A vast array of beauty: ornamental flower crops from Abutilon to Zinnia (common, scientific, and cultivar names) bred by Luther Burbank, year introduced, and origin/salient features (Burbank, 1914-15; Howard, 1945). ${ }^{\mathrm{z}}$

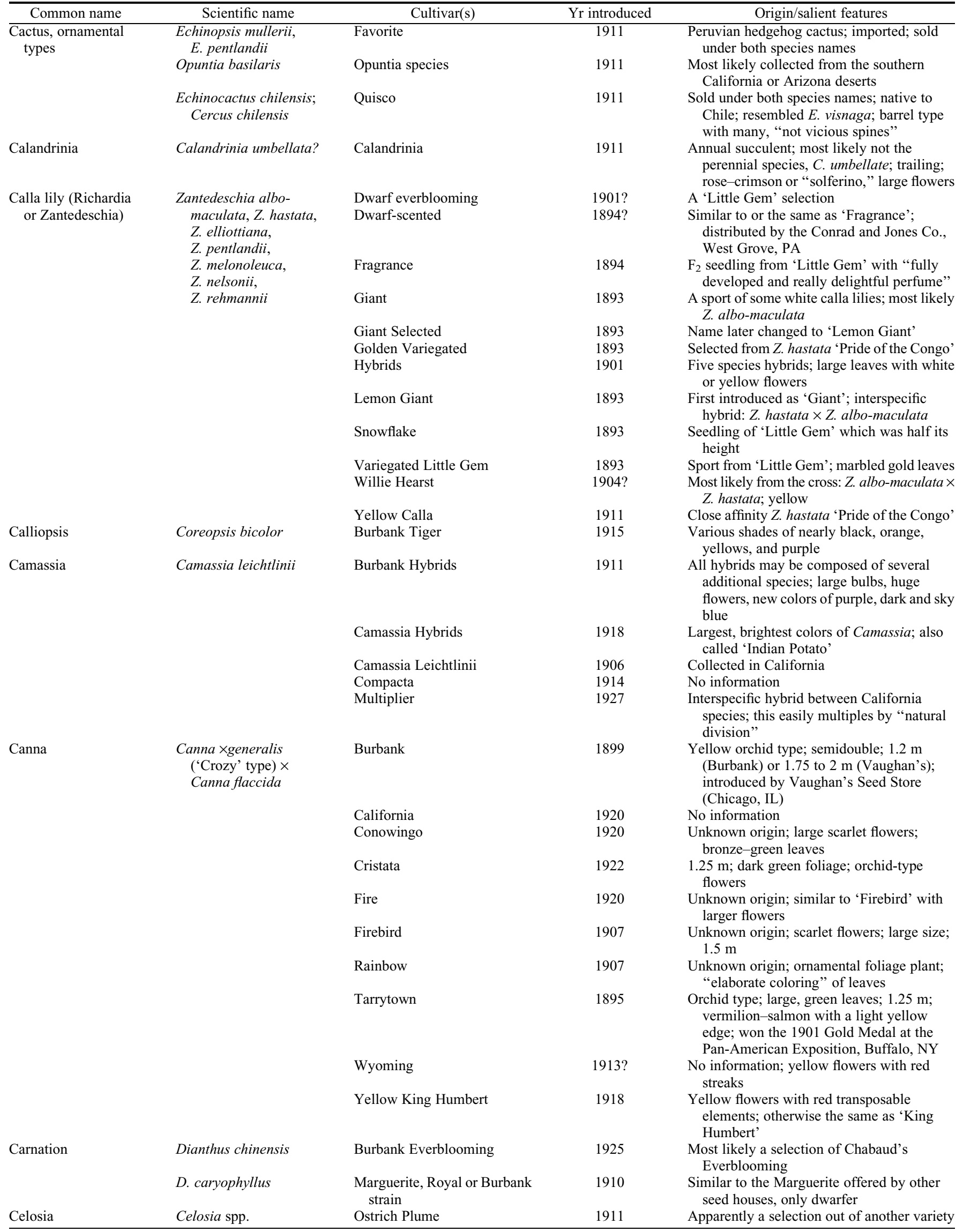


Table 1. (Continued) A vast array of beauty: ornamental flower crops from Abutilon to Zinnia (common, scientific, and cultivar names) bred by Luther Burbank, year introduced, and origin/salient features (Burbank, 1914-15; Howard, 1945). ${ }^{\mathrm{z}}$

\begin{tabular}{|c|c|c|c|c|}
\hline Common name & Scientific name & Cultivar(s) & Yr introduced & Origin/salient features \\
\hline $\begin{array}{l}\text { Chilean Blue } \\
\text { Flowering Bulbous } \\
\text { Plant }\end{array}$ & $<$ Unknown $>$ & Burbank Selection & 1914 & $\begin{array}{l}\text { Released as a selection before having correct } \\
\text { nomenclature; from a collector in Chile; } \\
\text { summer flowering with } 2 \text {-foot stems, } \\
\text { cobalt blue to white }\end{array}$ \\
\hline & $\begin{array}{l}\text { C. jackmanii- } \\
\text { lanuginosa }\end{array}$ & Double Clematis & 1894 & No information \\
\hline & C. jackmanii & Jackman Hybrid Seedlings & 1892 & $\begin{array}{l}\text { Most likely the first announcement of the } \\
\text { 'Clematis Hybrids' (1893) }\end{array}$ \\
\hline & & Waverly & 1894 & From the 'Clematis Hybrids' \\
\hline \multirow[t]{2}{*}{ Columbine } & Aquilegia caerulea & $\begin{array}{l}\text { Burbank's New Clematis- } \\
\text { flowered }\end{array}$ & 1903 & $\begin{array}{l}\text { Crossed with a spurless cultivar; introduced } \\
\text { by Vaughan's Seed Store (Chicago, IL) }\end{array}$ \\
\hline & & New Hybrids & 1894 & Hybrid mix \\
\hline Coreopsis & $\begin{array}{l}\text { Coreopsis lanceolate } \\
\text { grandiflora }\end{array}$ & Burbank strain & 1911 & $\begin{array}{l}\text { Most likely a perennial, selected seedling } \\
\text { with yellow-gold flowers }\end{array}$ \\
\hline \multirow[t]{2}{*}{ Corn, Ornamental } & Zea mays variegata & Aurora & 1914 & An improved cultivar of 'Rainbow' \\
\hline & & Rainbow & 1911 & $\begin{array}{l}\mathrm{F}_{2} \text { seedlings selected for several years for six } \\
\text { stripes/leaf; from "quadri-colored" corn } \\
\text { (Germany) }\end{array}$ \\
\hline Crinum & $\begin{array}{l}\text { Crinum americanum, } \\
\text { C. amabile, } C . \\
\text { asiatica }\end{array}$ & Burbank Hybrids & $\begin{array}{l}1902,1906 \\
1914,1927\end{array}$ & $\begin{array}{l}\text { Interspecific hybrids of complex ancestry } \\
\text { (like his amaryllis or Hippeastrum) }\end{array}$ \\
\hline \multirow[t]{14}{*}{ Dahlia } & Dahlia juarezii & Burbank & 1903 & $\begin{array}{l}\text { Cactus type; Vaughan's Seed Store (Chicago, } \\
\text { IL) }\end{array}$ \\
\hline & & David Burpee & $1922 ?$ & No information \\
\hline & & Estrelia & 1903 & $\begin{array}{l}\text { Snow white cactus type; Vaughan's Seed } \\
\text { Store (Chicago, IL) }\end{array}$ \\
\hline & & Golden West & 1922 & No information \\
\hline & & Lavendera & 1918 & $\begin{array}{l}\text { 'Geisha' seedling; remained on the market } \\
\text { for many decades }\end{array}$ \\
\hline & & Marigold & 1903 & $\begin{array}{l}\text { Double; selected from 'Gloria'; Vaughan's } \\
\text { Seed Store (Chicago, IL) }\end{array}$ \\
\hline & & Mariposa & 1903 & $\begin{array}{l}\text { Upright habit, pale yellow; Vaughan's Seed } \\
\text { Store (Chicago, IL) }\end{array}$ \\
\hline & & Oakland & 1918 & $\begin{array}{l}\text { Large, pure white; became "the official } \\
\text { flower of the city of Oakland, California" } \\
\text { as a publicity stunt because this is not true }\end{array}$ \\
\hline & & Santa Rosa & 1903 & $\begin{array}{l}\text { Cactus type; fragrant, red with salmon tints; } \\
\text { Vaughan's Seed Store (Chicago, IL) }\end{array}$ \\
\hline & & Sebastopol & $\approx 1905$ & $\begin{array}{l}\text { Orange-red; remained on the market for } \\
\text { many decades }\end{array}$ \\
\hline & D. purpusii & Sonoma & 1903 & $\begin{array}{l}\text { Light yellow; Vaughan's Seed Store } \\
\text { (Chicago, IL) }\end{array}$ \\
\hline & & Dazzling & 1918 & $\begin{array}{l}\text { Scarlet; from crossing a cactus type with } \\
\text { a wild scarlet collected by Dr. Purpus in } \\
\text { Mexico; also known as 'Mountain Dahlia' }\end{array}$ \\
\hline & & Scarlet & 1918 & Cactus type, single \\
\hline & $\begin{array}{l}\text { D. purpusii } \times D \text {. } \\
\text { variabilis }\end{array}$ & Sunset & 1915 & Looked like tiger lilies from a distance \\
\hline
\end{tabular}


Table 1. (Continued) A vast array of beauty: ornamental flower crops from Abutilon to Zinnia (common, scientific, and cultivar names) bred by Luther Burbank, year introduced, and origin/salient features (Burbank, 1914-15; Howard, 1945). ${ }^{\mathrm{z}}$

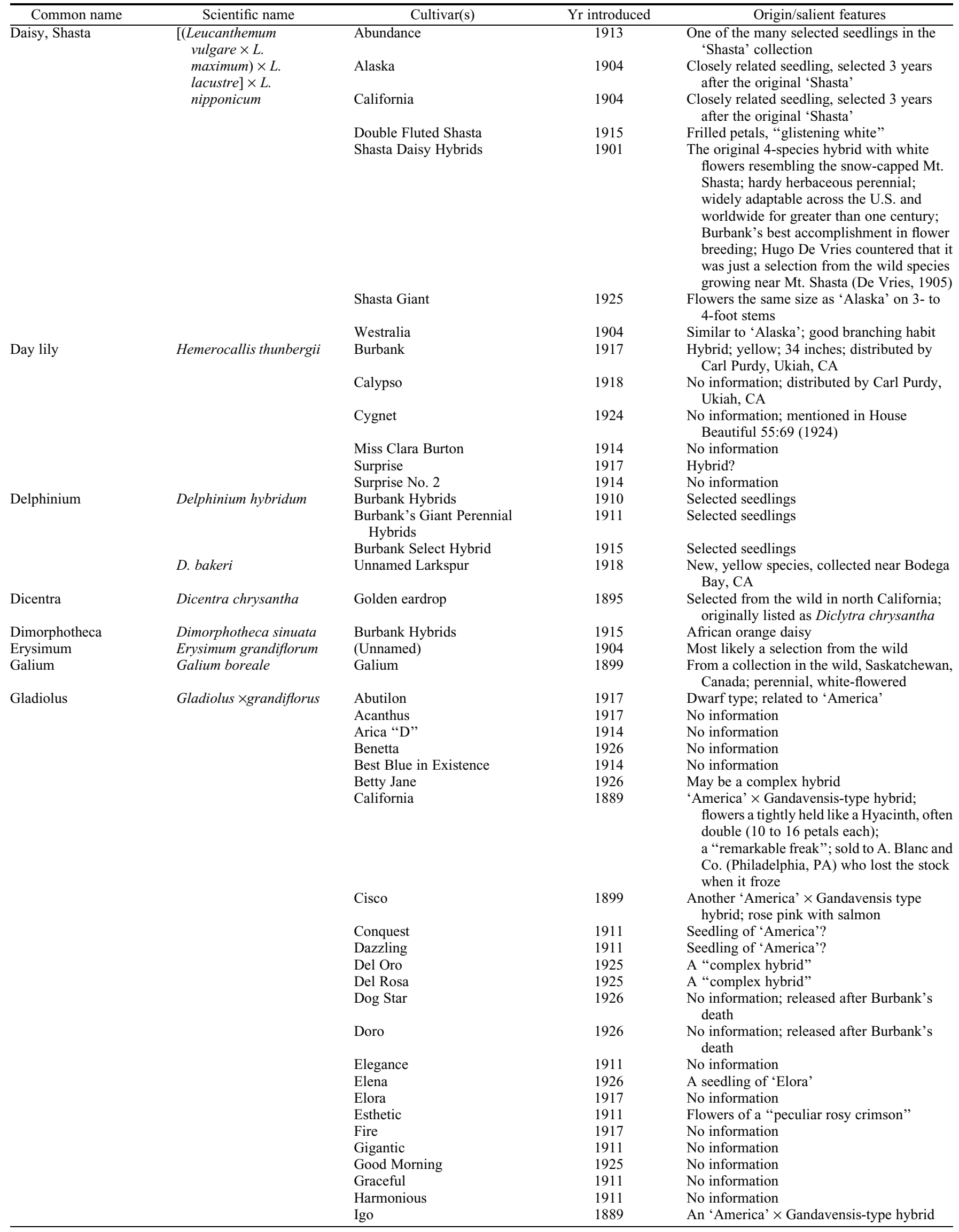


Table 1. (Continued) A vast array of beauty: ornamental flower crops from Abutilon to Zinnia (common, scientific, and cultivar names) bred by Luther Burbank, year introduced, and origin/salient features (Burbank, 1914-15; Howard, 1945). ${ }^{\mathrm{z}}$

\begin{tabular}{|c|c|c|c|c|}
\hline Common name & Scientific name & Cultivar(s) & Yr introduced & Origin/salient features \\
\hline & & Luther Burbank & 1926 & $\begin{array}{l}\text { Released after Burbank's death; } \\
\text { a multicultivar hybrid }\end{array}$ \\
\hline & & Mariposa & 1889 & $\begin{array}{l}\text { Most likely an 'America' } \times \text { Gandavensis- } \\
\text { type hybrid }\end{array}$ \\
\hline & & Mary Ellen & 1925 & No information \\
\hline & & Modesto & 1889 & An 'America' $\times$ Gandavensis-type hybrid \\
\hline & & Mono & 1889 & An 'America' $\times$ Gandavensis-type hybrid \\
\hline & & Navajo & 1926 & A result of "numerous crosses" \\
\hline & & Pentstemon & 1917 & A multicultivar hybrid; name misspelled \\
\hline & & Perla & 1926 & A multicultivar hybrid \\
\hline & & Pinnacle & 1911 & $\begin{array}{l}\text { Wide, broad petal, salmon-scarlet; purple } \\
\text { stamens; most likely an 'America' } \times \\
\text { Gandavensis-type hybrid }\end{array}$ \\
\hline & & Pohono & 1889 & $\begin{array}{l}\text { Most likely an 'America' } \times \text { Gandavensis- } \\
\text { type hybrid }\end{array}$ \\
\hline & & Seedling Gladioli & 1893 & Ten numbered seedlings \\
\hline & & Seedlings of California Strain & 1890 & Obviously seedlings of 'California' \\
\hline & & $\begin{array}{l}\text { Seeds of Burbank New } \\
\text { Hybrid Gladioli }\end{array}$ & 1914 & $\begin{array}{l}\text { Most likely 'America' } \times \text { Gandavensis-type } \\
\text { hybrids }\end{array}$ \\
\hline & & Shasta & 1889 & $\begin{array}{l}\text { Most likely an 'America' } \times \text { Gandavensis- } \\
\text { type hybrid }\end{array}$ \\
\hline & & Signal & 1911 & $\begin{array}{l}\text { Most likely an 'America' } \times \text { Gandavensis- } \\
\text { type hybrid }\end{array}$ \\
\hline & & Summit & 1926 & A multicultivar hybrid \\
\hline & & Symmetry & 1911 & $\begin{array}{l}\text { Most likely an 'America' } \times \text { Gandavensis- } \\
\text { type hybrid }\end{array}$ \\
\hline & & Tiger Face & 1926 & A multicultivar hybrid \\
\hline & & Waukena "F" & 1914 & No information \\
\hline Godetia & Godetia magellanica & $\begin{array}{l}\text { Burbank's New Lavender } \\
\text { Trailing }\end{array}$ & 1910 & $\begin{array}{l}\text { From a Chilean collector; trails when } \\
\text { vegetative then upright upon flowering } \\
\text { (similar habit to English ivy, Hedera helix) }\end{array}$ \\
\hline & C. quila & New Dwarf Pampas grass & 1901 & $\begin{array}{l}\text { Mislabeled as Gynerium jubatum; discovered } \\
\text { in South America; } 2 \text { months earlier than } \\
\text { other types; introduced by John Lewis } \\
\text { Childs in } 1903\end{array}$ \\
\hline & Pennisetum setaceum & New Paraguay Fountain Grass & 1921 & $\begin{array}{l}\text { Collected by Guanaco Indians in South } \\
\text { America as directed by Francisco Mueller; } \\
\text { perennial }\end{array}$ \\
\hline & $\begin{array}{l}\text { P. ruppelii }(=P . \\
\text { ruppellianum })\end{array}$ & Pennisetum Ruppellianum & 1895 & Most likely imported from Ethiopia \\
\hline Hawthorn & Crataegus pinnatifida & Hawthorn & 1929 & $\begin{array}{l}\text { Shrub selection from seeds received from } \\
\text { Prof. Joseph Bailie, University of Nanking, } \\
\text { China }\end{array}$ \\
\hline Herbertia & Herbertia pulchella & Little Blue Tigridia & 1910 & $\begin{array}{l}\text { Listed } 1 \text { year later as } H \text {. platensis; blue; } \\
\text { resembled giant Tigridia }\end{array}$ \\
\hline Heuchera & Heuchera cristata & Heuchera & 1906 & $\begin{array}{l}\text { Burbank collected seeds of } H \text {. micrantha on } \\
\text { Mount Saint Helena (California); one } \\
\text { selection had crinkly leaves; in the fourth } \\
\text { generation of selfing or OP, most were } \\
\text { crinkled; named a new species }\end{array}$ \\
\hline Horehound & Marrubium vulgare & Golden Marrubium & 1921 & $\begin{array}{l}\text { Pure gold-colored leaves; selected from } \\
\text { a wild seedling; } 60 \% \text { of seedlings were } \\
\text { gold }\end{array}$ \\
\hline \multirow[t]{2}{*}{ Iris } & Iris laevigata & Unnamed & ND & Mixture from an entire seed lot \\
\hline & Sisyrinchium striatum & Chilean Giant Sisyrinchium & 1911 & $\begin{array}{l}\text { Species name assigned by Burbank; from } \\
\text { Chile; yellow flowers; } 1.2 \mathrm{~m}\end{array}$ \\
\hline Lavender & Lavandula angustifolia & Pinnacle & 1923 & No information; sold directly to a distributor \\
\hline
\end{tabular}


Table 1. (Continued) A vast array of beauty: ornamental flower crops from Abutilon to Zinnia (common, scientific, and cultivar names) bred by Luther Burbank, year introduced, and origin/salient features (Burbank, 1914-15; Howard, 1945). ${ }^{\mathrm{z}}$

\begin{tabular}{|c|c|c|c|c|}
\hline Common name & Scientific name & Cultivar(s) & Yr introduced & Origin/salient features \\
\hline \multirow{4}{*}{ Lily } & $\begin{array}{l}\text { parryi, L. maritimum, } \\
\text { L. auratum, } L \text {. }\end{array}$ & Hybrid lilies & $1893-4$ & $\begin{array}{l}\text { Two offered in 1893; multiples in } 1894 ; \\
\text { numerous species in these interspecifics }\end{array}$ \\
\hline & batemanniae, $L$. & Hybrid P-2,854 & 1893 & L. pardalinum only \\
\hline & $\begin{array}{l}\text { florum, L. martagon, } \\
\text { L. parvum, } \\
\text { L. speciosum, } \\
\text { L. superbum, } \\
\text { L. tigrinum, } \\
\text { L. wallichianum, } \\
\text { L. purpureum }\end{array}$ & Hybrid P-72,721 & 1893 & $\begin{array}{l}\text { Most likely selected from } L . \text { pardalinum; } \\
\text { original dwarf parent plant collected on } \\
\text { Pluton Creek (north California) }\end{array}$ \\
\hline & L. bloomerianum & Wild Species of Lily & 1888 & L. maritimum and/or L. humboldtii \\
\hline Lippia & $\begin{array}{l}\text { Lippia canescens } \\
\quad(=\text { L. repens })\end{array}$ & Dixie & 1909 & $\begin{array}{l}\text { A replacement for lawn grasses; purportedly } \\
\text { collected in Chile but others in the United } \\
\text { States were from Rome, Italy }\end{array}$ \\
\hline \multirow{3}{*}{ Marigold } & T. erecta & Chilean Fragrant & 1911 & $\begin{array}{l}\text { From a Chilean seed lot; exact species } \\
\text { unknown }\end{array}$ \\
\hline & & Corona & 1925 & Unknown hybrid \\
\hline & & Giant Calendula & ND & No information \\
\hline \multirow[t]{2}{*}{ Mimulus } & Mimulus cardinalis & New Hybrids & 1904 & $\begin{array}{l}\text { Range of flower colors (yellow, red, orange, } \\
\text { pink, white) }\end{array}$ \\
\hline & Mimuls grandis & M. Grandis & ND & $\begin{array}{l}\text { A "rare California perennial" collected in } \\
\text { the wild }\end{array}$ \\
\hline Montbretia & $\begin{array}{l}\text { Crocosmia spp. } \\
\quad(=\text { Montbretia })\end{array}$ & New California Strain & 1888 & $\begin{array}{l}\text { "Like small gladioli"; selected or collected } \\
\text { in the wild }\end{array}$ \\
\hline Morning-glory & Ipomoea purpurea & Burbank's Giant Crimson & 113 & "Imperial carmine" flowers \\
\hline \multirow[t]{2}{*}{ Myrtle } & Myrtus ugni & Improved Chilean & 1916 & $\begin{array}{l}\text { From Chile; edible huckleberry fruit, } \\
\text { bronze-red; evergreen shrub } 0.75 \text { to } 1 \mathrm{~m}\end{array}$ \\
\hline & Myrtus communis & New Myrtle & 1893 & Silver variegation; mutation \\
\hline \multirow[t]{2}{*}{ Penstemon } & Penstemon spp. & Burbank Scarlet Bugle & 1915 & Mislabelled as "Pentstemon"; 0.5 to $0.75 \mathrm{~m}$ \\
\hline & & Crimson & 1914 & No information \\
\hline \multirow[t]{2}{*}{ Platycodon } & Platycodon grandiflora & Japanese Bell & 1910 & Blue and white \\
\hline & & New Double White & 1919 & Perennial; dwarf to $0.75 \mathrm{~m}$ \\
\hline \multirow[t]{3}{*}{$\begin{array}{l}\text { Plum, Chinese } \\
\text { climbing }\end{array}$} & Actinidia chinensis & Mao-li-dzi & 1910 & $\begin{array}{l}\text { Received from a Chinese collector; } \\
\text { resembled plums but not a Prunus; furry } \\
\text { skin; small seeds }\end{array}$ \\
\hline & $\begin{array}{l}\text { Actinida agrita } \\
\quad \text { (A. arguta?) }\end{array}$ & Tara & 1910 & Korean seedling; climbing vine \\
\hline & Actinidia chinensis & Yang-tao & 1910 & Less hardy than 'Mao-li-dzi' but similar fruit \\
\hline $\begin{array}{l}\text { Plum, Ornamental } \\
\text { Blackleaf }\end{array}$ & Prunus cerasifera & Thunder Cloud & 1919 & $\begin{array}{l}\text { Most likely a selection from the 'Myrobalan' } \\
\text { rootstock; with purpled leaves }\end{array}$ \\
\hline \multirow[t]{8}{*}{ Poppy, CA } & $\begin{array}{r}\text { Eschscholtzia } \\
\text { californica }\end{array}$ & $\begin{array}{l}\text { Burbank Crimson } \\
\text { Eschscholtzia }\end{array}$ & 1904 & $\begin{array}{l}\text { Red selection; distributed by Burpee Seed } \\
\text { Co. (Philadelphia, PA) }\end{array}$ \\
\hline & & $\begin{array}{l}\text { Burbank Reselected Giant } \\
\text { White }\end{array}$ & 1911 & Best white \\
\hline & & Extra Mixed & 1900 & White, yellow, red in the strain \\
\hline & & Firefly & 1915 & Light yellow with crimson \\
\hline & & Golden Cup & 1907 & $\begin{array}{l}\text { Red; distributed by the Santa Rosa, CA, } \\
\text { Chamber of Commerce }\end{array}$ \\
\hline & & Mixed & 1911 & Shades of all colors Burbank developed \\
\hline & & Orange Cream & 1919 & Released as Papaver californicum \\
\hline & & Pink Eschscholtzia & $1900 ?$ & $\begin{array}{l}\text { No information; distributed by Burpee Seed } \\
\text { Co. (Philadelphia, PA) }\end{array}$ \\
\hline
\end{tabular}

(Continued on next page) 
Table 1. (Continued) A vast array of beauty: ornamental flower crops from Abutilon to Zinnia (common, scientific, and cultivar names) bred by Luther Burbank, year introduced, and origin/salient features (Burbank, 1914-15; Howard, 1945). ${ }^{\mathrm{z}}$

\begin{tabular}{|c|c|c|c|c|}
\hline Common name & Scientific name & Cultivar(s) & Yr introduced & Origin/salient features \\
\hline \multirow[t]{6}{*}{ Poppy, Shirley } & Papaver rhoeas & $\begin{array}{l}\text { Burbank Mixture of Blue } \\
\text { Shades }\end{array}$ & 1913 & Perhaps the same as 'Celestial White' \\
\hline & & Burbank Strain & 1911 & From 10 years of selection \\
\hline & & Celestial Strain & 1910 & $\begin{array}{l}\text { Pink, salmon, white shades; "crimped" } \\
\text { petals }\end{array}$ \\
\hline & & Giant Shirley & 1920 & Papaver rhoeas $\times P$. glaucum hybrid \\
\hline & & Shirley Art Poppies & 1921 & White to pink to salmon; crepe-like petals \\
\hline & $\begin{array}{l}\text { P. rhoeas var. } \\
\text { umbrosum }\end{array}$ & Silver Lining & 1893 & $\begin{array}{l}\text { Sport with silver white on the inside of the } \\
\text { petals; red outside; distributed by } \\
\text { Burpee Seed Co. (Philadelphia, PA) }\end{array}$ \\
\hline Poppy, Prickly & Argemone munita & Mariposa & 1922 & Red-flowered selection from the wild \\
\hline \multirow[t]{2}{*}{ Poppy, Opium } & Papaver somniferum & Queen & 1892 & No information \\
\hline & & Rosy Giant & 1921 & $1 \mathrm{~m}$ tall \\
\hline Primrose, Evening & Oenothera acaulis & America & 1910 & $\begin{array}{l}\text { Flat-flowered, nearly } 4.5 \text { to } 5 \text { inches in } \\
\text { width; "snowy white"; came true } \\
\text { from seed }\end{array}$ \\
\hline Quince, Ornamental & Chaenomeles japonica & Dazzle & 1893 & No information \\
\hline \multirow[t]{11}{*}{ Rose } & Rosa $\times$ hybrida & Burbank & 1899 & $\begin{array}{l}\text { Rosy crimson hybrid from crossing } \\
\text { 'Hermosa' × 'Bon Silene'; introduced } \\
\text { by W. Atlee Burpee Co. (Philadelphia, } \\
\text { PA) in 1900; won the Louisiana } \\
\text { Purchase Exposition Gold Medal, } \\
\text { St. Louis, MO, in 1904; reintroduced } \\
\text { by Stark Brothers (Louisiana, MO) in } \\
1936\end{array}$ \\
\hline & & Peachblow & 1893 & $\begin{array}{l}\text { M-17,806 rose seedling; hybrid tea; pale } \\
\text { silver-peach/pink inside of petals; } \\
\text { outside a "dark, bronzy carmine-pink }\end{array}$ \\
\hline & & Pipette & 1909 & $\begin{array}{l}\text { Parents included 'Bon Silene', 'Hermosa', } \\
\text { etc. }\end{array}$ \\
\hline & & Rose of Oregon & 1909 & $\begin{array}{l}\text { Sent to the Portland, OR, Rose Carnival, } \\
22 \text { Feb. } 1909\end{array}$ \\
\hline & & $\begin{array}{l}\text { Santa Rosa (Hybrid } \\
\text { bourbon Tea) }\end{array}$ & 1898 & $\begin{array}{l}\mathrm{F}_{2} \text { seedling of 'Hermosa'; shell pink } \\
\text { flowers; double-reflexed; Burbank sold } \\
\text { this retail }\end{array}$ \\
\hline & & Seedling Rose H. 813 & 1893 & 'Hermosa' seedling; rich pink \\
\hline & & Seedling Rose J. 26,940 & 1893 & Similar to 'General Jacqueminot' \\
\hline & & Seedling Rose M. 11,120 & 1893 & Everblooming; mixed seed lot \\
\hline & & Seedling Rose M. 19,928 & 1893 & $\begin{array}{l}\text { Resembled 'Papa Gontier' with additional } \\
\text { petalage }\end{array}$ \\
\hline & & Waynoka No. 59 & 1914 & No information \\
\hline & Rosa rugosa & Rugosa Hybrids & 1893 & $\begin{array}{l}\text { Pink climber; awarded a California Floral } \\
\text { Society medal }\end{array}$ \\
\hline \multirow[t]{2}{*}{ Scilla } & Scilla peruviana & Burbank Scilla & 1914 & Peruvian species; deep blue \\
\hline & Scilla autumnalis & German Scilla & 1914 & $\begin{array}{l}\text { Blue/white mix; dist. by Luther Burbank } \\
\text { Co. (San Francisco, CA) }\end{array}$ \\
\hline Scyphanthus & Scyphanthus elegans & Unnamed & 1908 & Chilean import; gold \\
\hline Silphium & Silphium laciniatum & Square Plant & 1916 & $\begin{array}{l}\text { From the Midwest states; square stems; } \\
\text { yellow }\end{array}$ \\
\hline
\end{tabular}

(Continued on next page) 
Table 1. (Continued) A vast array of beauty: ornamental flower crops from Abutilon to Zinnia (common, scientific, and cultivar names) bred by Luther Burbank, year introduced, and origin/salient features (Burbank, 1914-15; Howard, 1945). ${ }^{\mathrm{z}}$

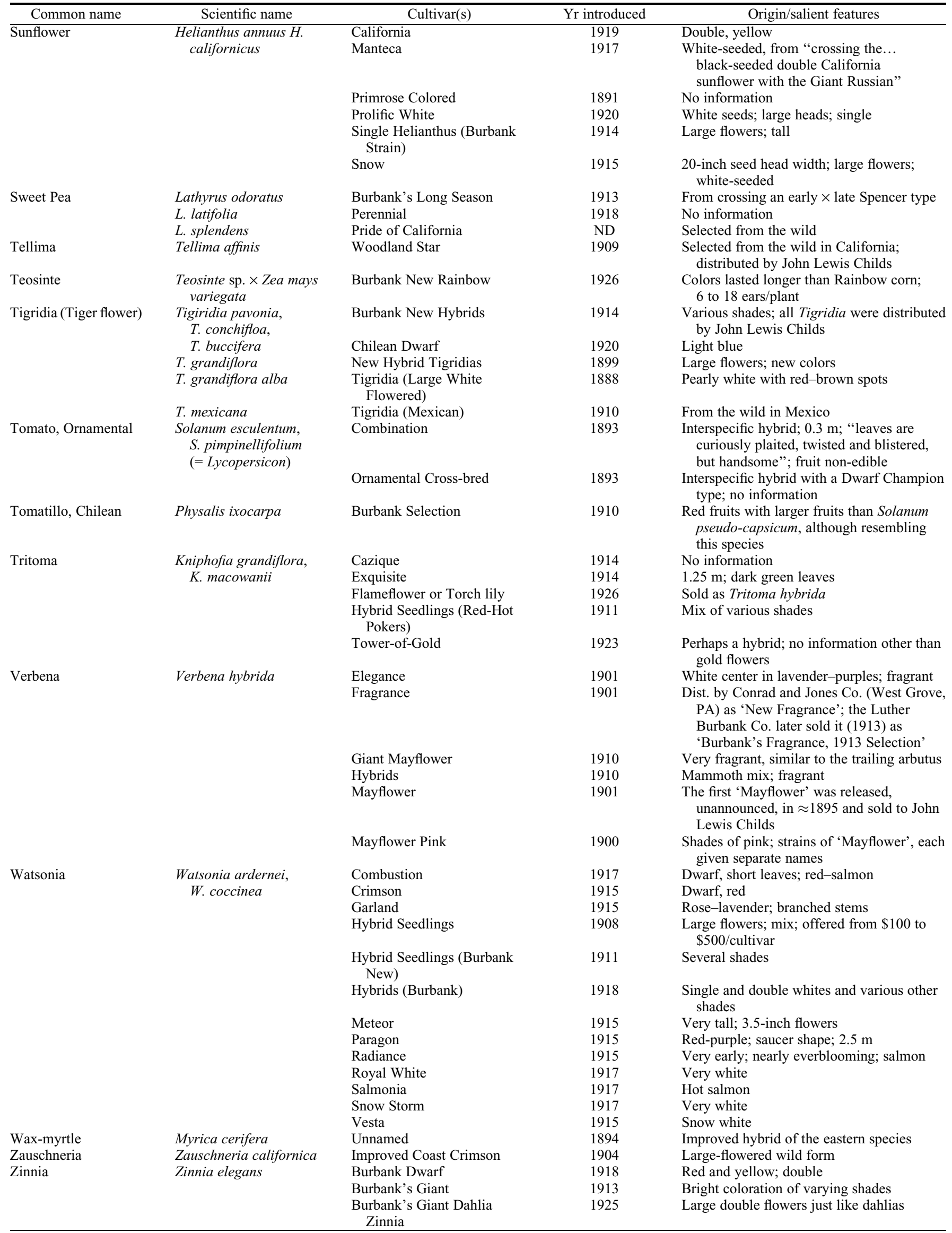

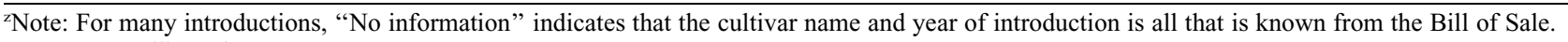
$\mathrm{OP}=$ open-pollinated. 
him to breed and select a vast array of beauty in ornamentals during his lifetime: 91 genera of flowers from Abutilon to Zinnia with nearly 1000 cultivars released to the industry (Table 1), which no competitor could equal and few-if any-individual breeder has done since. Even Claude Hope, a founder of PanAmerican Seed Company, bred numerous products, but not as many as Luther Burbank (Martinez, 1992). Genera with the highest number of cultivars bred and released by Burbank include Amaryllis, Hippeastrum, and Crinum followed by Lilium, Hemerocallis, Watsonia, Papaver, Gladiolus, Dahlia, and Rosa (Table 1).

Two of Burbank's outstanding ornamental and/or edible herbaceous cultivars - the shasta daisy and spineless cacti (discussed below) - were derived from germplasm provided by numerous collectors worldwide (Howard, 1945). The constant need for incorporating wild germplasm into cultivated ornamental crops is still an imperative for any modern flower breeder to avoid inherent risks associated with narrow cultivar bases, e.g., North American Easter lily sales are based on a single cultivar, Nellie White, which is experiencing clonal decline after greater than 60 years of asexual propagation (Zlesak et al., 2007; Zlesak and Anderson, 2007). Similarly, specific environmental requirements to flower Pelargonium domesticum (Martha Washington geraniums) and Fuchsia $\times$ hybrida have limited their seasonality to spring conditions although intraspecific, wild germplasm exists with genes and alleles that promote flowering in high temperatures (Anderson, 2006).

Mass breeding. Because Luther did most of the breeding, selection, and grow-outs of his complex hybrids, it was not unusual for a guest to see him busily working in the fields. For instance, crossing was often done outdoors without pollen protection or emasculation of composite flower crops such as Calendula officinalis (Fig. 2). Thus, many of his pollinations were often contaminated with self-pollinations or other pollen sources brought in by pollinators or wind. As such, grow-outs required selection of off-types at the seedling or transplant stages, if possible. This practice is still in use with ornamental seed crops that are OP, e.g., Capsicum annuum, Dahlia variabilis, Delphinium hybridum, etc. (PanAmerican Seed Company, 1999) and most, if not all, heirloom flowers and vegetables.

Burbank became famous as a mass breeder, growing up advanced selections and generations en masse in the fields and harvesting immense seed quantities (Fig. 1B). Hugo De Vries, famous for his discovery of genetics independently from Gregor Mendel, referred to Burbank as "the greatest mass breeder of plants in either Europe or America" (De Vries, 1905). Slate (1939) wrote on Burbank's mass breeding of Lilium that his was "probably the most extensive lily hybridizing project ever undertaken" such that, by 1894, Luther had 3 acres of seedlings derived from crossing $L$. pardalinum with a large number of male parents, which were native, Pacific coast species. Purdy (1895) noted that from mass selection, breeding of "extreme" or off-types for several generations, created a population with "every intermediate form...from giants nine feet tall to dwarfs from six inches to a foot in height." Many "freaks and monstrosities" were created such that some seedlings had the recurved petals of L. pardalinum transformed into either flat petals or trumpets and the entire population of greater than 100,000 hybrids were fragrant (unlike L. pardalinum, the original female seed parent) and could be smelled miles away (Purdy, 1895).

Lack of record-keeping and hybrid mixups. Keeping accurate records is an essential feature of modern plant breeding and genetics, but Luther Burbank was more interested in profitable results than in process and his few record books were consequently non-scientific. One critic even said that he "was constitutionally incapable of keeping careful notes" (Smith, 2009). He did not keep careful records and was not interested in process, but rather products with market value and, in so doing, maintain secrecy. Such secrecy continues to permeate private sector plant breeding, although most modern breeders do maintain good notebooks. Only a few notebooks and a 5000-page scrapbook remain from his years of extensive breeding (Howard, 1945) in which he wrote notes on seedlings with reference to their potential marketable qualities (Fig. 3). For example, reading through his notes on the "Hybrid Best Selected" Lilium "of 1882 flowering," Selection Nos. 1 to 16, dated 10 Nov. 1882 (Fig. 3), he wrote that seedling No. 2 was variegated, whereas No. 3 was the tallest flowering plant, etc.

Hugo De Vries, and other scientists such as George H. Shull, noted that Burbank's keen "eye" and excellent memory meant that he could nearly always identify the male parent of a seedling without any records for referral (Howard, 1945). Interestingly to Burbank, making a cross was an experimentalthough most were uncontrolled and non-scientific. In fact, the subtitle to the volumes of his "autobiography" says that his discoveries were "prepared from his original field notes covering more than 100,000 experiments..." (Burbank, 1914-15). Although mass breeding does not require extensive record-keeping as, say pedigree breeding, nonetheless, accurate records enable future breeders working on a crop to remake crosses or continue pedigrees and breeding objectives (Allard, 1960). This lack of records and incorrect labeling as well as Burbank's practice of selling off new introductions to wholesalers caused hybrid mixups to occur or multiple names were attached to the same plant. Some of these errors continue to the present day with confusion over his hybrid rose introductions, 'Burbank' and 'Santa Rosa'. Both of these cultivars were derived from a cross between Rosa 'Bon Silene' and an 'Hermosa' seedling (Burbank, 1914-15) but they were both released by different companies or Burbank himself (Howard, 1945). Had records of phenotypic differences between the two

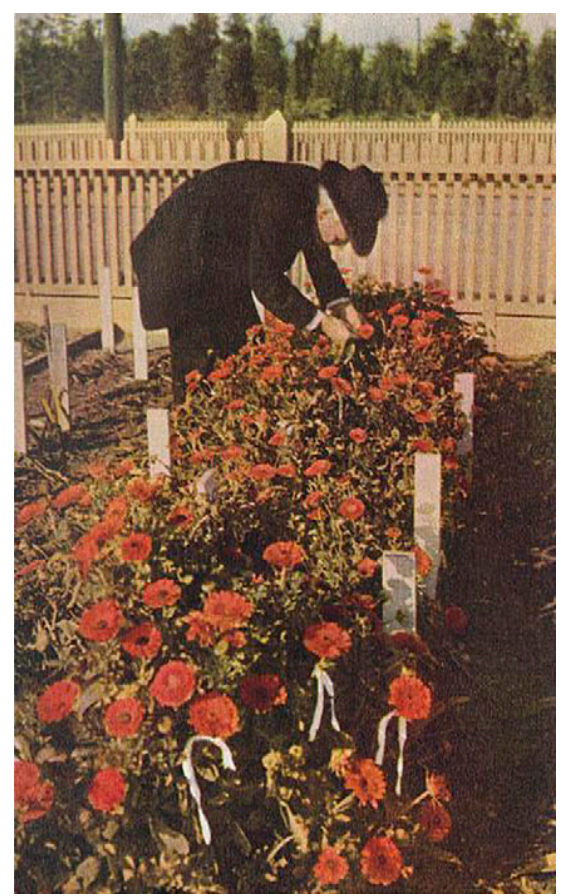

Fig. 2. Luther Burbank making crosses of Calendula officinalis. Note tall white row markers demarcating different parents or hybrid populations and the white cloth "tags" denoting crosses (Burbank, 1914-15)

seedlings existed, these could have cleared up the continuing confusion of these two cultivars. Despite extreme care exerted by producer and distributor companies, hybrid mixups are still recurring phenomena (Anderson et al., 2010). Likewise, in modern-day private sector breeding programs, for instance, a flower breeder may not necessarily breed the same crop(s) during their lifetime, so continuity is lost when records are poorly kept. Sadly, when Burbank died, the vast majority of his breeding knowledge kept in his memory vanished forever.

De Vries and mutations. Hugo De Vries (Fig. 4) made two trips to California in 1904 and 1906 during Burbank's life to lecture at the University of California (De Vries, 1905). However, De Vries visited Burbank each time for a few days to visit with him and discuss the origin of new traits or mutations and develop a theory on their origination. De Vries was disappointed by Burbank's disbelief in mutants and who remained adamant that new traits in his hybrids were the products of recombination through wide crosses derived from "pre-existing old characters" (Howard, 1945). The novel, variegated leaves found in a seedling Acer negundo (Fig. 5), for instance, was viewed as an ancient trait now being expressed despite its rarity as "the only hardy tree known that produces such beautiful variegated foliage" (Burbank, 1914-15).

During these midcareer years, Burbank was called on to talk at the 1902 International Conference on Plant Breeding and Hybridization and the growing circle of plant breeders and early geneticists wanted to hear more 


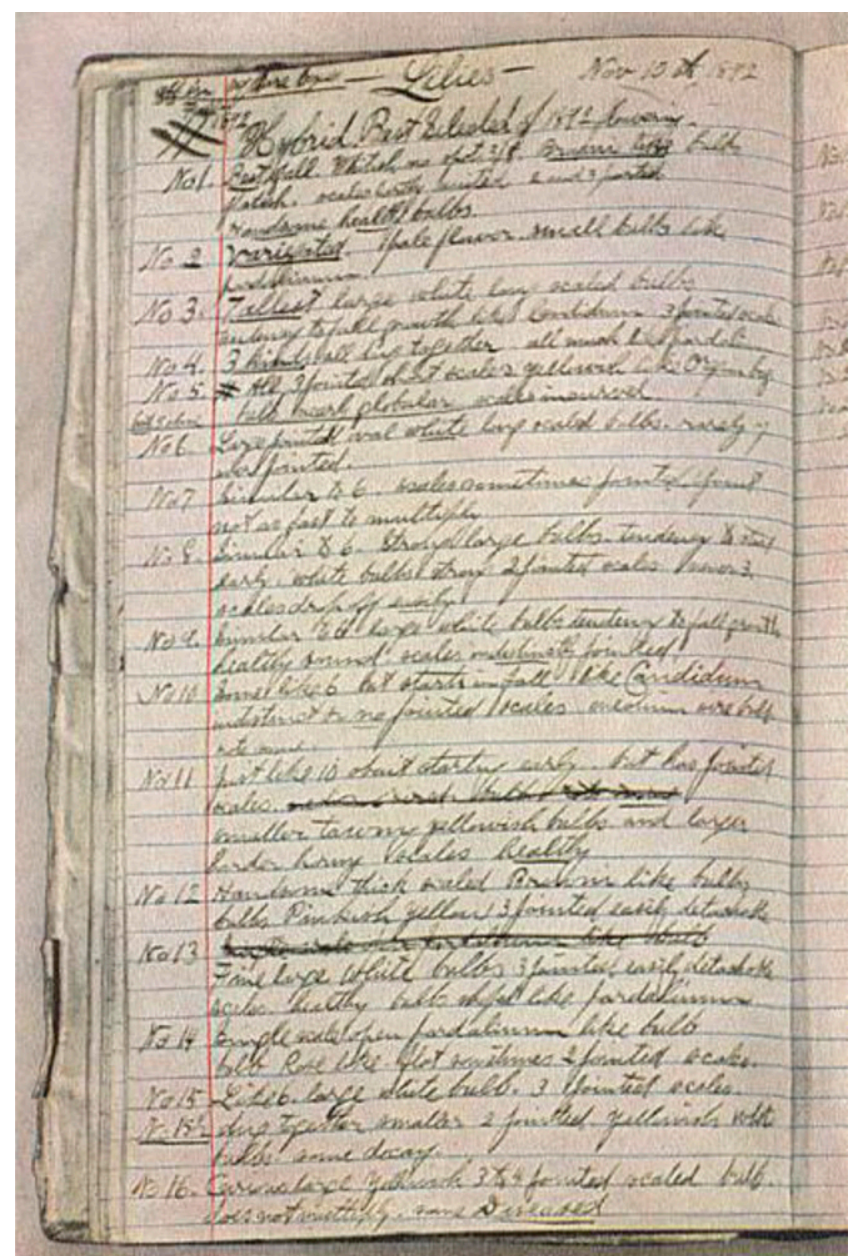

Fig. 3. Sample breeding records for "Hybrid Best Selected" Lilium "of 1882 flowering," Selection Nos. 1 to 16 , dated 10 Nov. 1882 (Burbank, 1914-15). Note No. 2 was variegated, whereas No. 3 was the tallest flowering plant.

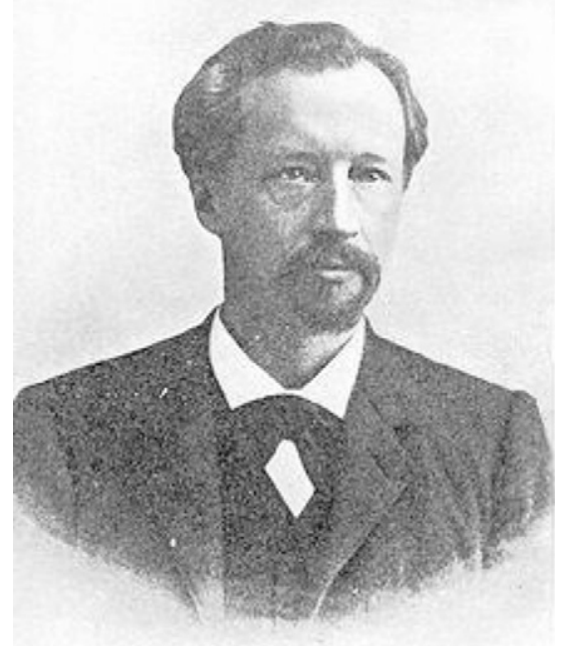

Fig. 4. Hugo De Vries visited Burbank in 1904 and 1906 and hoped that he would explain the origin of mutants (De Vries, 1905).

about his scientific methods (Smith, 2009). Indeed, 2 years later the Carnegie Institution entertained the first funding nomination for
Such a grant catapulted Burbank to national fame with numerous articles subsequently appearing about this "wonder worker of science" (Smith, 2009). Satiric poetry and cartoons appeared frequently in the popular press such as The Los Angeles Times and Harper's Monthly (Smith, 2009). This funding lasted for only 5 years, ceasing as a result of numerous reasons, not the least of which was the lack of information that Burbank was supposed to supply to George Harrison Shull for the Carnegie Institution (Smith, 2009). Shull, a trained biologist who later founded the scientific journal Genetics, was required to file a report for publication; Burbank was loathe to divulge his breeding techniques for publication and obfuscated Shull's efforts completely (Crow, 2001). Later, the scientific community withdrew its support of Burbank as a result of his reluctance to share experimental techniques - in contrast with the scientists' information exchange-and that most of his techniques were not unusual although his eye for selection was acute.

\section{BURBANK TECHNIQUES WITH MODERN RELEVANCE}

Flower power and convenience. In 21 st century flower breeding, successful floricultural crops - particularly annual bedding plants - have to possess flower power and convenience (Anderson, 2006; Anderson et al., 2006a, 2006b). Flower power denotes the presence of large, showy flowers with minimal foliar displays and/or colorful foliage plants of trendy colors, patterns, and forms. Convenience refers to the ease of production, distribution, growing, postharvest adaptation, and long shelf or vase life at retail followed by superior performance with minimal maintenance inputs by the consumer (Anderson, 2006). Both tenets of modern flower breeding were exemplified by Burbank because he was at the cusp of the discovery of modern genetics and hybrid vigor.

Burbank worked for several decades breeding bulbous or geophytic relatives in the Amaryllidaceae, notably amaryllis (mainly, Hippeastrum but also Amaryllis) Crinum, and Sprekelia (Burbank, 1909, 1914-15). $\mathrm{He}$ discovered that wide intraspecific, interspecific, and intergeneric crosses produced progeny that, when backcrossed, selfed, or cross-pollinated (mass or OP) for two to three generations, resulted in segregants with immense flower sizes and/or increased numbers thereof. Selections of such types created increased flower power in many crops. After several years of interbreeding and selection of bulbous Hippeastrum vittatum, $H$. reginae, and $H$. johnsonii, a "colony of mixed hybrids" of significant difference from ancestral forms was produced, which he termed the "Giant Amaryllis" (Burbank, 1914-15; Howard, 1945). Wide, intergeneric crosses involving $\mathrm{Ama}$ ryllis belladonna $($ female $) \times$ Crinum americanum (male) produced larger petal sizes in amaryllis (Fig. 6A). Other products emerging from the race of "Giant Amaryllis" 
included new floral patterns such as the classic 'Apple Blossom' hybrid (Fig. 6B), which are still popular today as well as double flowers produced from turning anthers and filaments into petals (Fig. 6C). Burbank released as many as eight to 10 named amaryllis cultivars (Table 1) and a large number of hybrid selections (136 at one time, consisting of 3117 bulbs at an average price of U.S. $\$ 1.55$ each), which were sold unnamed (Burbank, 1909, 1914-15; Howard, 1945). Many of the named cultivars were sold to John Lewis Childs, some of which were listed in his 1909 catalog. All of the original cultivars have now disappeared but their Giant Amaryllis descendants still populate the market as winter and spring bulbous houseplants.

The 'Apple Blossom' vittatum types in the Giant Amaryllis collection were subsequently used to cross with the Jacobean lily, Sprekelia formosissima (Table 1). Only one transgressive segregant from the wide, intergeneric cross actually flowered and produced seed, but it possessed immense flowers, 12 inches $(30.5 \mathrm{~cm})$ in diameter, with twisted petals unlike either parent; it was released as 'Martinique' (Fig. 7). Other intergeneric crosses were not as successful and became controversial. For instance, Burbank claimed that he crossed Amaryllis belladonna $\times$ Crinum americanum, which produced only sterile progeny with oddly shaped leaves (Howard, 1945). His critics did not believe the validity of this cross, proposing that it was equally likely the male parent could have been $C$. amabile (=C. augustum), C. asiaticum, $C$. moorei, or $C$. longifolium for these were also in Burbank's breeding nursery (Howard, 1945). Dr. Geoge H. Shull who worked for the Carnegie Institution (Washington, DC)-from which Burbank had received a research grant-spent 5 years confirming the scientific validity of this and other crosses. Dr. Shull at least weakly acknowledged that a cross between Amaryllis belladonna and a Crinum species had been made (Howard, 1945). As a final note, the intergeneric cross does exist, now recognized as $\times$ Amaricrinum (Ingram, 1975) and, although Burbank's hybrid has been lost, other crosses are commercially available.

Luther Burbank focused on a variety of other flower crops to increase flower size. In the marigolds (Calendula officinalis, Tagetes patula, T. erecta), he created series of flower types with varying numbers of petals. In the case of Calendula, he released a cultivar, Giant Calendula, with extremely large flowers (Table 1) as well as a series ranging from duplex types (two rows of disc florets) to fully doubles (Fig. 8). He termed the process of breeding such series as "educating the Calendula" (Burbank, 1914-15). Interspecific Crinum, derived from crossing "tropical species with our native [N. American] Florida species" also reached immense sizes with bulbs weighing as much as 7 pounds $(3.2 \mathrm{~kg})$ with large, fragrant flowers from the tropical species but with the added "hardiness of the natives" (Fig. 9) (Burbank, 1914-15). Crinum 'White Queen', a Burbank hybrid
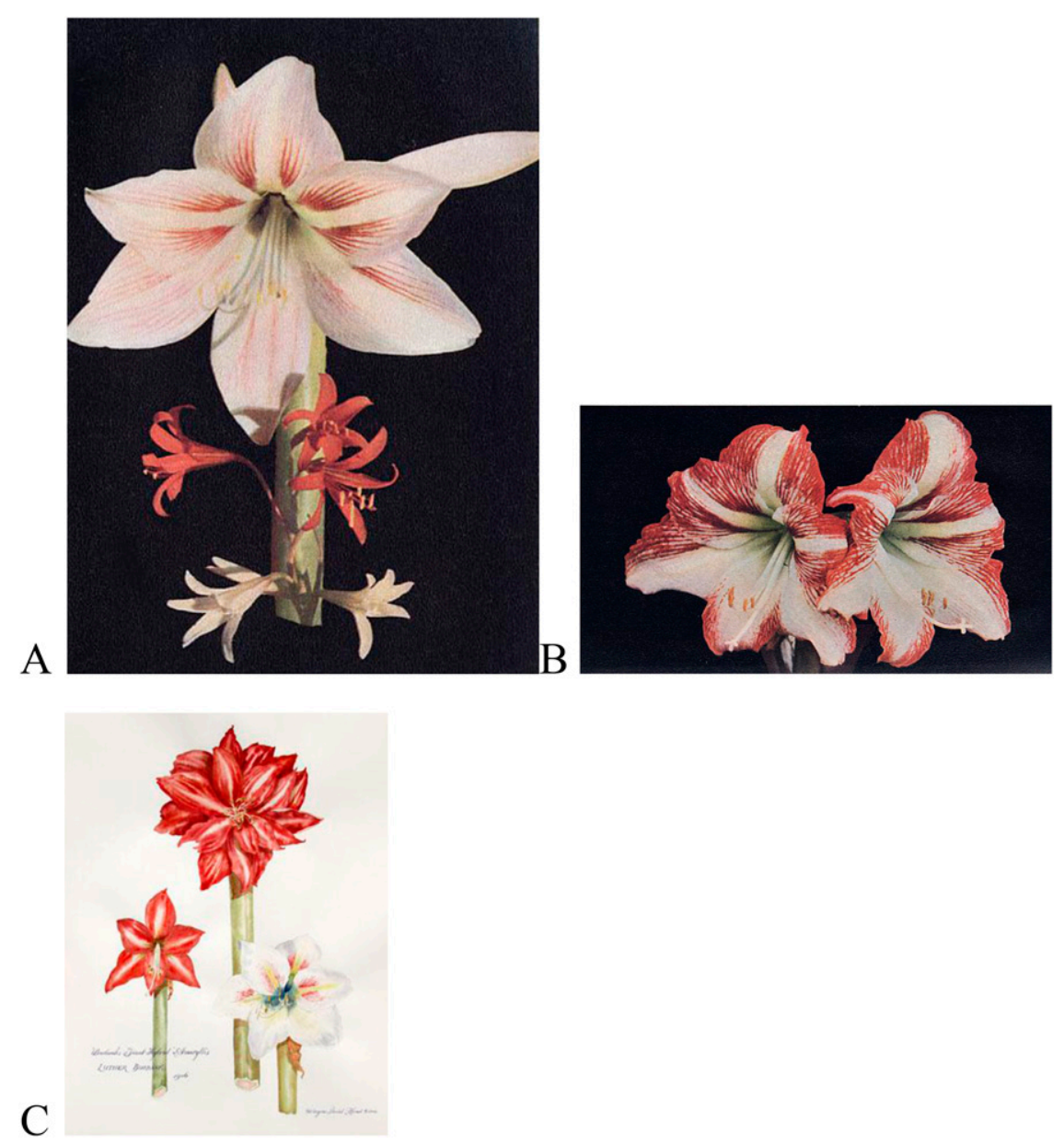

Fig. 6. Wide crosses produce huge flowers: (A) the cross Amaryllis belladonna (top) $\times$ Crinum americanum (lower two sets of flowers) produced even larger-sized amaryllis flowers (B) depicted by the famous 'Apple Blossom' hybrid; even double flowers were produced from turning anthers and filaments into petals (C) (Burbank, 1914-15).

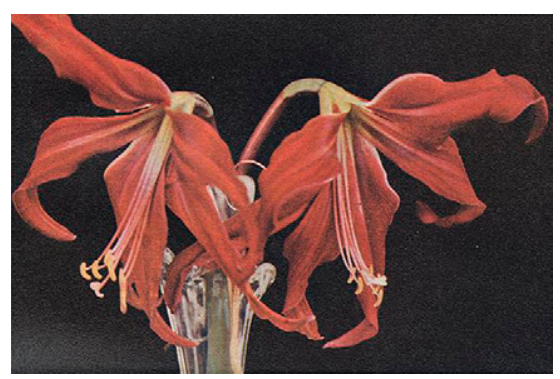

Fig. 7. Burbank's Giant Amaryllis 'Martinique', an intergeneric hybrid (Hippeastrum [= Amaryllis] vittatum $\times$ Sprekelia formosissima) producing flowers 12 inches in diameter (Burbank, 1914-15).

released after his death by his assistant, Bill Henderson, is an example, with large, wide white and fragrant flowers on "massive bulbs, and leaves up to ten feet long" (Kelly, 1983). Although no breeding records exist explaining the crosses within daylilies (Hemerocallis), of the several cultivars that were released to the market (Table 1), 'Surprise' has immense light yellow flowers for the year (1917) in which it was released (Fig. 10). Burbank mentioned this as a "cross-bred

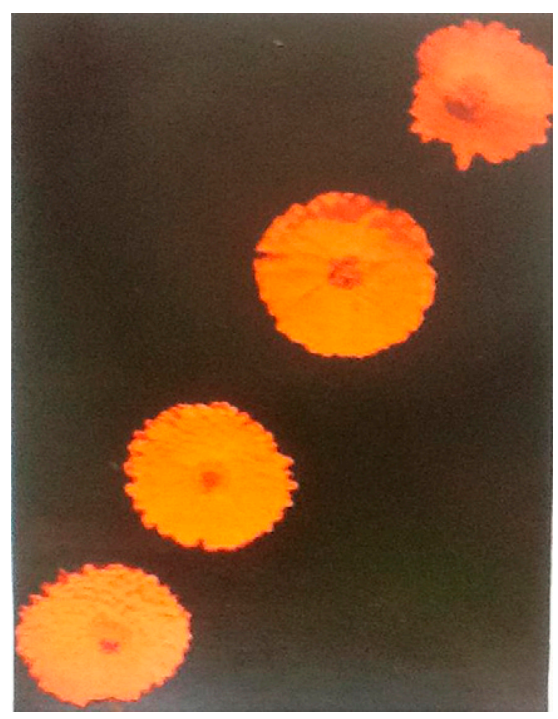

Fig. 8. Educating the Calendula (C. officinalis): double (lower left) to duplex (upper right) flower types (Burbank, 1914-15).

seedling," but no other pedigree information is known as a result of a lack of records (Burbank, 1917, 1918b). Another example of increased flower size is Oenothera 'The 
America' (Fig. 11) which Burbank described as having petals so large they "...would completely cover the entire flower of any other evening primrose on the market. These gigantic flowers look like pocket handkerchiefs thickly strewn over the foliage" creating a glowing effect at dusk (Burbank, 1914-15). Breeding for increased flower sizes and/or enhanced petal production (changing singles into doubles) continues unabated as a primary focus of modern flower breeders, although it is not always possible to achieve in every crop. For instance, Tagetes patula (dwarf french marigolds) have never had significant increases in flower size beyond the initial breeding efforts. Such species' limits were aptly described by Burbank's statement: "if new habits are hard to start, new traits are even harder" (Burbank, 1914-15).

Variegated tropical ornamentals. Variegation in tropical foliage plants commenced

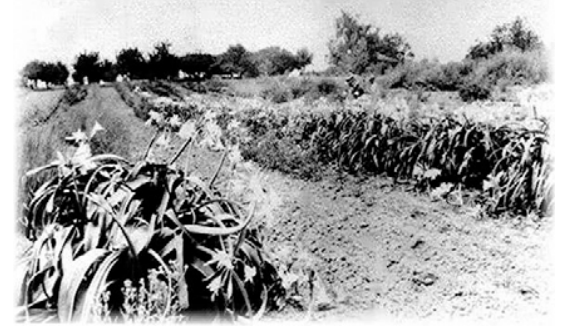

Fig. 9. Hybrid Crinum interspecific hybrid lilies of immense size from crossing "several tropical species with our native Florida species" growing in the Sebastopol trial gardens. Bulbs were as large as 7 pounds produced flowers with the "size, beauty and fragrance of the tropical species with the hardiness of the natives" (Burbank, 1914-15).

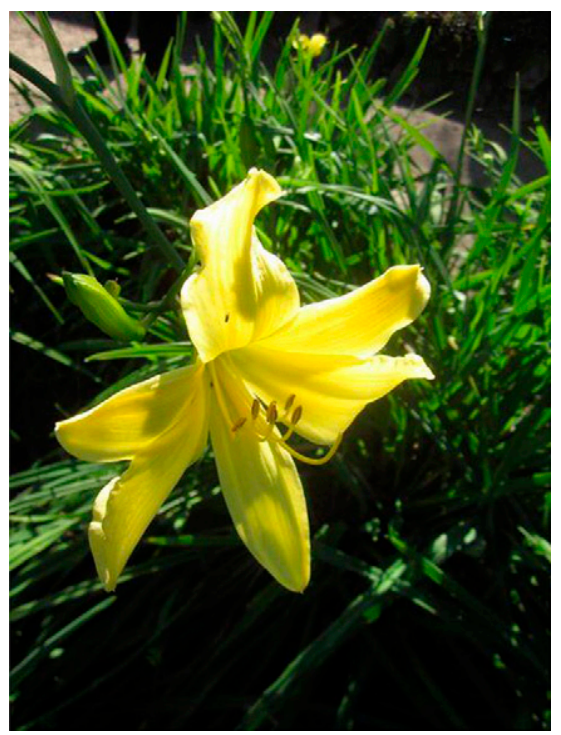

Fig. 10. Hemerocallis 'Surprise' is a clear yellow with immense flower size for the time in which it was bred (Burbank, 1914-15). during this time period and consumer interest in them has continued to the present day. Burbank contributed to canna development at the tail end of the first wave of interest in these tropical perennials. Coincidentally, Burbank unknowingly crossed a canna 'Crozy'-hybrid selection with Canna flaccida, a North American native to produce an Orchid-type canna just after Italian breeders had [except they used a different 'Crozy' strain (Howard, 1945)]. Subsequent crossing and selection of these interspecific hybrids resulted in numerous canna cultivars (Table 1), the best of which were 'Burbank' (Fig. 12A) and 'Tarrytown' (Burbank, 1911). 'Burbank', sporting lovely clear yellow and white flowers with a few transposable elements in the throat grew to 3.5 feet $(1.25 \mathrm{~m})$ in the first year and as high as 5 to 6 feet $(\approx 1.75 \mathrm{~m})$ in the second year, was sold through Vaughn Seed Company and the Luther Burbank Company, although Burbank retained some control because he also sold it retail in 1911 (Burbank, 1911, 1914-15, 1915b, 1920b). The cultivars Rainbow and Yellow King Humbert (Fig. 12B and C) were both variegated cannas with 'Rainbow' being compared as an equal to "New Giant or Rainbow-Leaved Coleus" (Burbank, 1914-15). 'Yellow King Humbert' sports sectorial leaf variegations (Fig. 12B) with speckled (transposable elements) and chimeric flower petals (Fig. 12C) and is still available in the nursery industry.

Flower surround and increased density. Indeterminant inflorescences that are spicose, racemose, panicled, or thyrse types have flowers spaced along the stems. Some wild species may have the flowers pointing

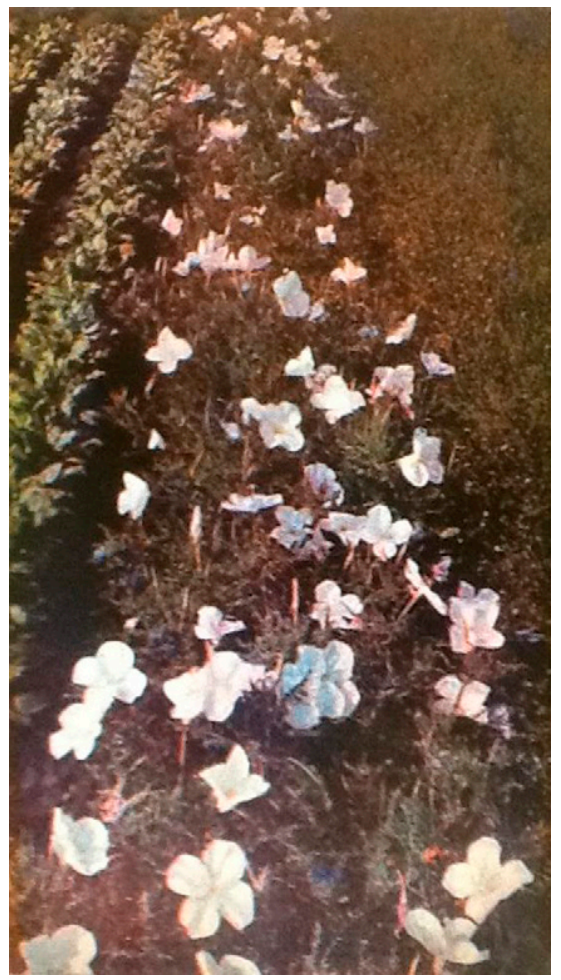

Fig. 11. Enhanced flower size produced in Oenothera 'The America' (Burbank, 1914-15). upward or outward from the nodes at anthesis but many do not and are faced (flowers on just one side of the stem), e.g., Gladiolus and Delphinium. In floral design, faced-flower types are commonly used in one-sided designs such as funeral bouquets (Hunter, 2012). Although faced inflorescences are useful, significantly greater flower power arises if the floral positioning can be rotated around the stem (flower surround), providing a $360^{\circ}$ view, increasing their value for bedding plants, herbaceous perennials, cut flowers, and flowering potted plant use (Anderson, 2006). Burbank sought to change floral display in larkspur or delphiniums, sowing a population of the species Delphinium hybridum, which trace back primarily to D. elatum (Burbank, 1914-15). He selected one seedling closest to his breeding objective, sowing the seeds from it and released one cultivar but discarded the remainder, although he released three series that were all derived from $D$. hybridum (Table 1). All of these series had been bred and selected for flower surround and increased flower density (Fig. 13) such that there was very little space between the individual flowers. Breeding for both flower surround and increased density are common domesticated traits incorporated by modern flower breeders.

Luther Burbank also attempted to cross in the tall $D$. californicum species with $D$. hybridum but met with a high failure rate. Eventually he made different interspecific crosses, releasing an unnamed hybrid that had yellow flowers derived from another native California species, most likely the coastal $D$. bakeri. To the best of our knowledge, all of Burbank's Delphinium hybrids have vanished but most likely the gene(s) and allele(s) he selected for flower surround and increased density remain in modern Delphinium such as Pacific Giant hybrids, possibly bred with other Delphinium spp. by Frank Reinelt, a self-taught Czech flower breeder who, after emigrating to the United States, founded Vetterle \& Reinelt Company in nearby Capitola, CA.

"Harnessing heredity" with new flower colors. Modern marketing criteria for new floral products, once the first cultivar is released, are the rapid development of a wide-ranging color palette with as many flower colors as can be generated within the species to form a series (Anderson, 2006). Many such series on the market consist of cultivars - each with a different flower color-that share a common female parent but differ in the male parents (Anderson, 2006), such that the resultant hybrid cultivars are half-sib families. The desire for new or enhanced flower colors to follow the fashion trends each year (Anderson, 2006; Hunter, 2012) was developing in Burbank's time. He devoted considerable effort to breeding new flower colors in as many genera and species as possible to enhance sales (Burbank, 1914-15).

Like with so many other breeding objectives and techniques used, Burbank used many native California species that he saw traveling between Santa Rosa and Sebastopol, CA, as well as plant collection trips 

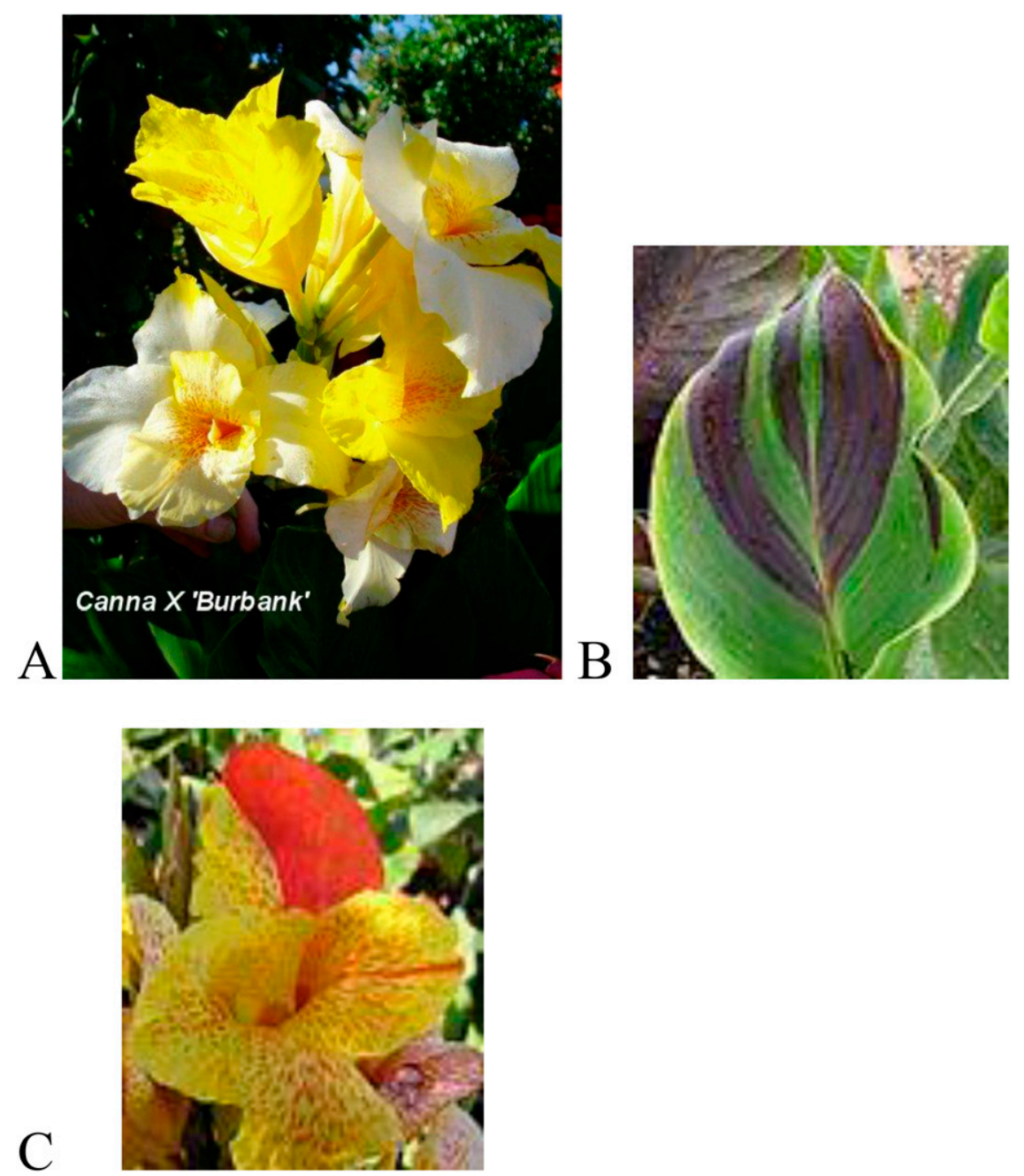

Fig. 12. Canna 'Burbank' (A) resulted from crossing 'Crozy' $\times$ C. flaccida $(<\mathrm{http}: / / 3$.bp.blogspot.com/ JhMjOi3-rUE/R4L8QdZh89I/AAAAAAAAAGQ/PAnyHyPboLU/s1600-h/Burbank2.jpg>); 'Yellow King Humbert', in the Italian Group of the genus, with variegated leaves (B) and speckled, chimeric flowers (C). Burbank is reputed to be the first to recognize and name this Canna 'Roi Humbert' mutation (Burbank, 1914-15).

through the state. The California poppy, Eschscholtzia californica, grows throughout the coastal foothills but the annual species predominantly has yellow-orange flowers. Burbank "harnessed heredity" (Burbank, 1914-15) and bred or selected new flower colors, particularly red ones, named 'Crimson' (Fig. 14A) and sold in 1904 to the W. Atlee Burpee Company in Philadelphia, PA, at that time (Table 1; Burbank, 1914-15; Howard, 1945). He enhanced the intensity of the orange through selection and also released 'Fire Flame' (Fig. 14B) or, perhaps, 'Firefly' as a result of different sources naming it differently (compare Burbank, 1915b and Howard, 1945). Subsequently, white and pink forms also were selected from wild sources (Fig. 14C). White ones were derived from light yellow types and, most likely, were the result of a homozygous recessive allelic configuration. Other examples evoking flower color changes not present in wild species included Osteospermum hybrids insourced from South Africa by an unknown collector/supplier. He created orange (Fig. 15A) and pink (Fig. 15B) daisy as a separate cultivar. How he accomplished breeding a red iris is a mystery because current-day amateur iris breeders have determined that the carotenoid pigments necessary to produce red iris flowers do not exist in the genus (Meckenstock, 2005)!

Fixing traits. In contrast with blue flower color, a trait that could not be "fixed" in Shirley poppy, Papaver rhoeas (Burbank, 1925; Howard, 1945), some floral species Burbank found had traits that were easily or "readily fixed" and came true from seed (Burbank, 1914-15). Such was the case with the annual sunflower, Helianthus annuus (Fig. 17). However, because these were OP hybrids, the off-types had to be rogued out. Although the breeding records for this crop are scant, he worked with both $H$. annuus and $H$. californicus with interspecific breeding objectives to increase seed yield, seedcoat coloration, and flower size (Howard, 1945). $\mathrm{He}$ released single- ('Prolific White', released in 1920) and double-flowered forms ('California', released in 1919; Table 1). Additionally, seedcoat colors of pure white ('Manteca', released in 1917; 'Prolific White'; 'Snow' released in 1915; Table 1) were released. Most of the flower forms and seed types are still commonly bred and grown throughout North America, favored as bedding plants and garden cultivars.

Lilium and wide, intersectional crosses. Lilies were a crop that Burbank focused on with intensity. Indeed, one lily expert critical of Burbank said that his breeding within the genus was his finest contributions (Howard, 1945). The immense scale with which he undertook breeding this genus in 1875 was unrivaled by other ornamental crops (Slate, 1939). Nineteen years later, Burbank had 3 acres (1.2 ha) devoted to his hybrid lilies. With Lilium, he pioneered breeding the North American native lily species (section Pseudolirion), particularly those from the Pacific coastal region (L. washingtonianum, L. humboldtii, $L$. parryi, L. pardalinum, and L. maritimum), and he is honored in the interspecific hybrid name, L. $\times$ burbankii, for hybrids between $L$. parryi $\times$ L. pardalinum (Slate, 1939).

The Pacific coast lily species - particularly L. pardalinum - were most often used as seed parents, although to make intersectional, interspecific hybrids, Burbank also used lily species as male parents from eastern North America (section Martagon-L. parryi, L. parvum, L. superbum; section Pseudolirium-L. washingtonianum) and Eurasia (section Archelirion- $L$. auratum, L. brownii, L. speciosum; section Leucolirion-L. longiflorum, L. wallichianum; section Liriotypus - L. candidum, L. chalcedonicum; section Martagon-L. martagon). Most phenotypic traits were rarely visible in these hybrids (Slate, 1939). Several thousand crosses were made through the years (Purdy, $1895)$ to create massive segregating populations for further intermating and selection. Purdy (1895) reported seeing 400,000 1 -year-old lily seedlings in 1891 that segregated for true leaf phenotypes. The vast seedling beds (from sowing 1 to 3 pounds of lily seed/year) were highly selected by virus 


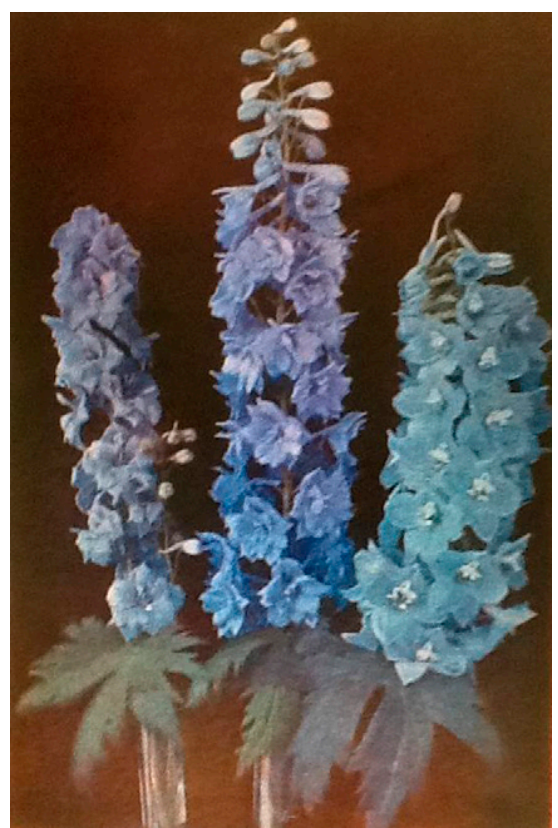

Fig. 13. Delphinium: increased flower density and stem surround (Burbank, 1914-15). and other criteria with selection differentials as high as $75 \%$. Three years later greater than 100,000 were in flower by mid-June 1894, nearly all of which "were fragrant," which was perceptible 5 miles $(8 \mathrm{~km})$ away (Purdy, 1895); a wide range of flower phenotypes was observed (recurved, Turk's caps and semitrumpets to previously unknown horizontal types). Hybrid vigor or heterosis was widely observed throughout the segregating populations, particularly hybrids from the cross $L$. parryi $\times$ L. humboldtii (Purdy, 1895) with floriferous stems (30 to greater than 100 flowers/stalk). Other floriferous hybrids were derived from $L$. pardalinum var. minor $\times L$. maritimum and L. pardalinum var. minor crossed with an unknown male species, which created a "tree lily" that, in Year 6, had multiple flowering branches with as many as 207 flowers/bulb (Purdy, 1895). Three species hybrids or triple hybrid lilies exhibited outstanding heterosis. Purdy (1895) reported observing $L$. parryii $\times L$. washingtonianum $\times$ $L$. pardalinum hybrids that ranged from 18 inches $(45 \mathrm{~cm})$ to 8 feet $(2.43 \mathrm{~m})$ in height (Fig. 18). Some 50 years later, W.L. Howard (1945) wrote that Burbank's lily breeding was
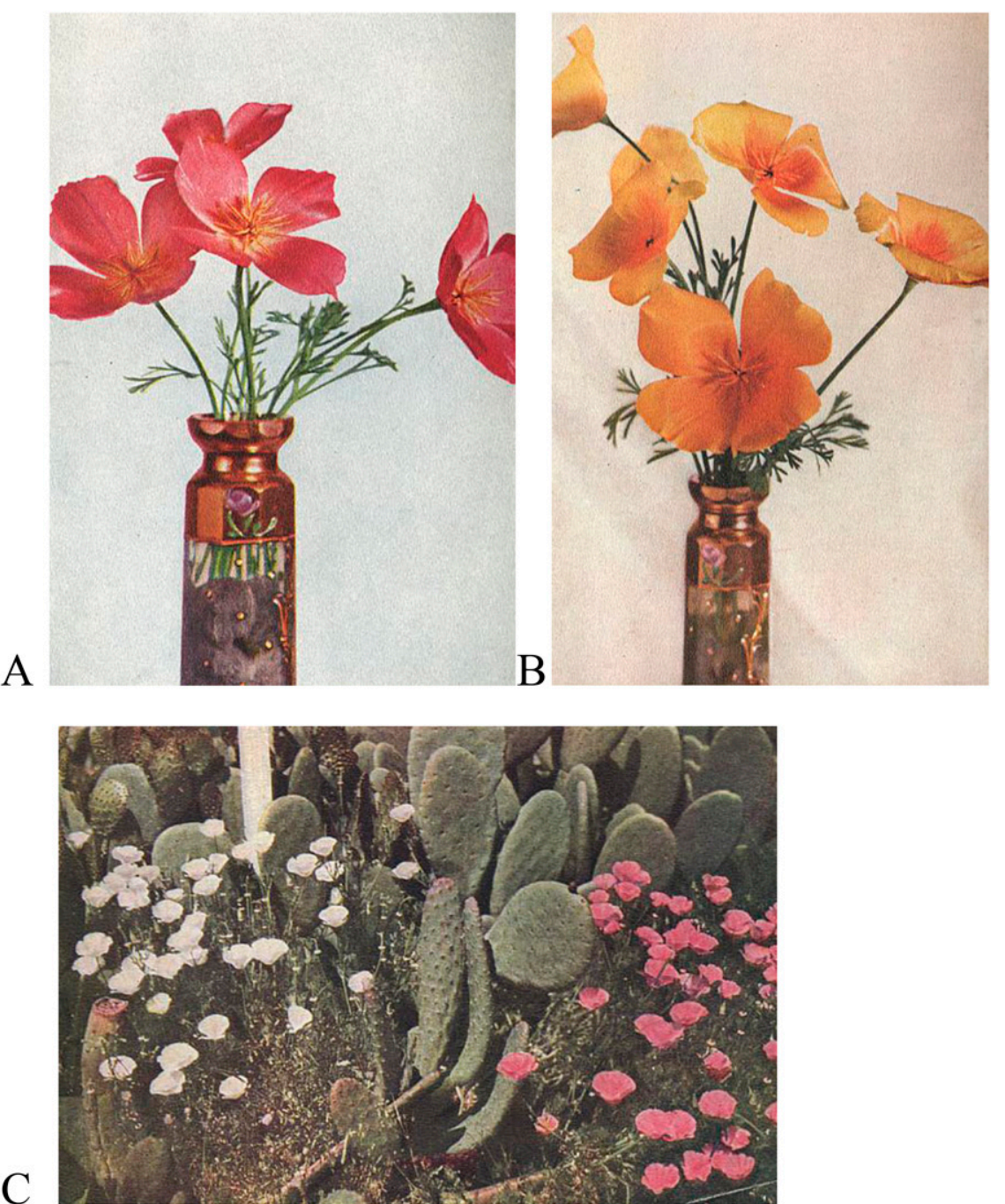

Fig. 14. New flower colors in Eschscholtzia californica. (A) 'Crimson', (B) 'Fire Flame', (C) white and pink selections growing alongside the spineless cacti seedlings (Burbank, 1914-15). "boldly conceived and audaciously executed" although he only released one named cultivar ('Burbank') and a few unnamed seedlings (Table 1). None of these survived 50 years later primarily as a result of virus buildup in lily clones (Howard, 1945). Lily Latent Virus or Lily Symptomless Virus (LSV) was not discovered until the 1930s (McWhorter, 1937). LSV buildup is a continuing issue in clonal cultivars, particularly Easter lily, $L$. longiflorum 'Nellie White' (Zlesak et al., 2007).

An "interesting failure": sterile, semitrailing intergeneric hybrids. Stretching the limits of crossability beyond the interspecific level, Burbank tried many different intergeneric crosses within ornamentals in the Amaryllidaceae [Crinum and Hippeastrum $(=$ Amaryllis)], Iridaceae (Tigridia and Ferraria), and Solanaceae (Nicotiana and Petunia) (Burbank, 1893, 1914-15). At least one outstanding ornamental, 'Nicotunia' or $\times$ Nicotunia, resulted from the intergeneric cross (made in 1893) between a Bolivian tobacco species with ruby flowers (Nicotiana wigandioides var. rubra) and a grandiflora petunia (Petunia hybrida var. grandiflora) (Burbank, 1893, 1914-15). As soon as the seeds ripened, they were sown $(\approx 200$ seedlings germinated) and then transplanted when $\approx 1$ foot $(0.3 \mathrm{~m})$ tall and kept over the winter in the glasshouse. The next spring they were transplanted into the field and began segregating for foliage coloration (green, pink, crimson; Burbank, 1893). By the next winter and spring, some seedlings fell over (lodged) and began trailing, whereas other dwarf types trailed without lodging. All hybrids were completely sterile (Howard, 1945) but could be propagated asexually (through cuttings) - a common propagation method in petunias at that time. Severe hybrid breakdown or incongruity (Hogenboom, 1974) occurred with a "pinched" above-ground phenotype and few roots (Burbank, 1914-15). Some hybrids had astounding phenotypes (Fig. 19) with petunia-like flowers and a trailing plant habit; the latter phenotype was not discovered again in the genus Petunia until the 1970s (Peter Ascher, personal communication, unpublished data) and the 1980s when the interspecific Wave ${ }^{T M}$ types emerged (Anderson, 2006). Sadly, all of the $\times$ Nicotunia hybrids froze to death the next winter because they remained unprotected in the field.

Sterility and everblooming (day-neutral). Sterility, a useful trait to prevent reseeding and spread of invasive ornamental species (Anderson, et al., 2006a, 2006b), also surfaced with interspecific hybridization of ornamental species. In the genus Papaver (poppy), he created interspecific hybrids by crossing annual and perennial species (Papaver somniferum $\times$ P. orientale; Fig. $20 \mathrm{~A}$ ) that by the $F_{2}$ generation of 2000 plants, began segregating for complete sterility (Fig. 20B; Burbank, 1914-15). Perhaps, as a result of sterility, these hybrids were "everblooming" throughout the growing season (Burbank, 1914-15). Burbank also created everblooming calla lilies, e.g., 'Dwarf Everblooming' 


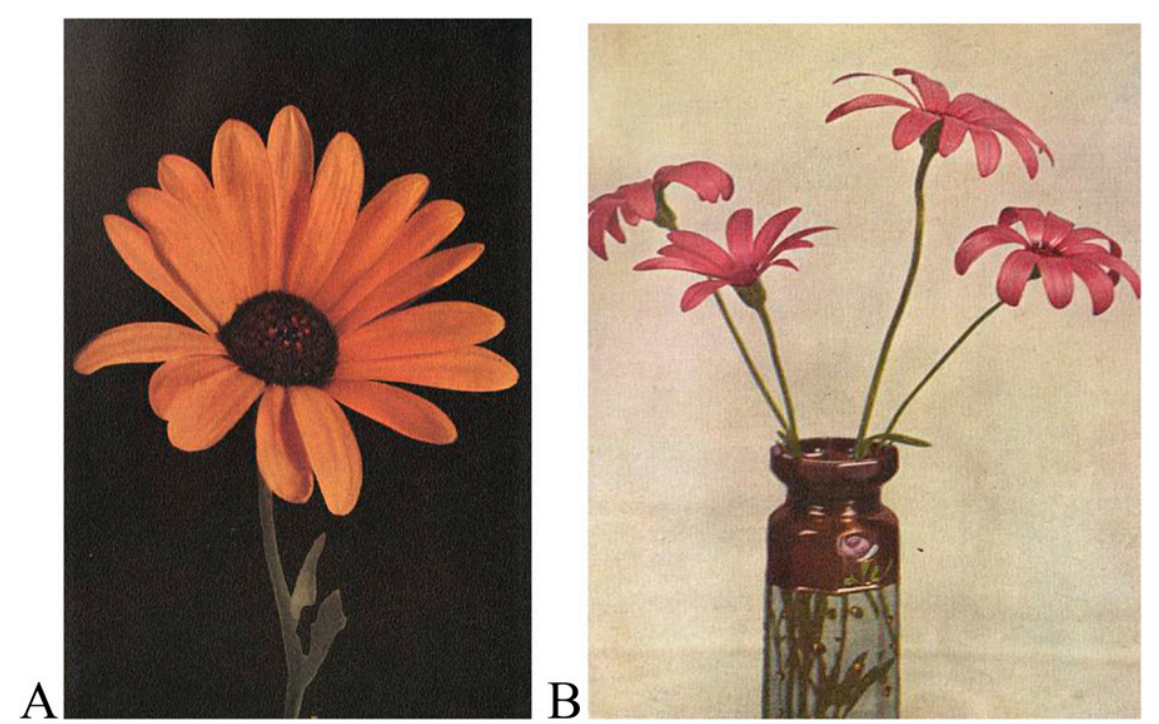

Fig. 15. Burbank's Osteospermum hybrids displaying new flower colors not present in the wild (A-orange; B - pink) as a result of "harnessing heredity" (Burbank, 1914-15), many of which have been recreated by modern-day breeders.
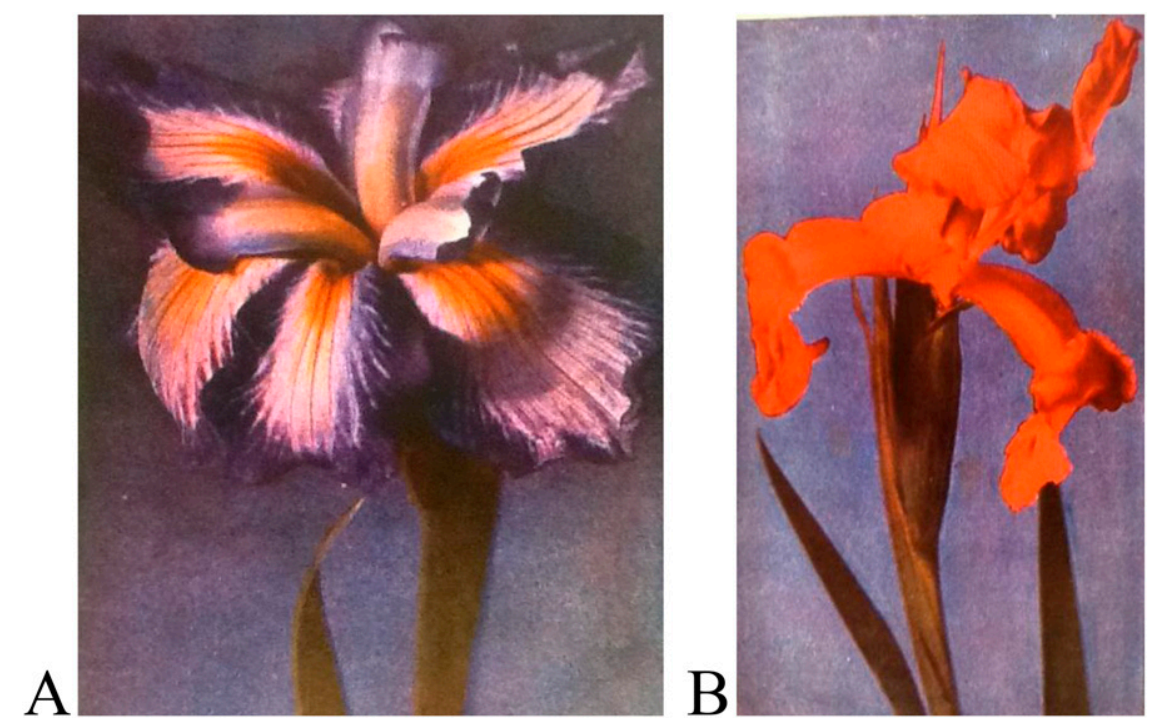

Fig. 16. Color blending (A) and new red color (B): "Improvements of the much-improved Iris" (Burbank, 1914-15).

(Table 1). The "everblooming" trait, now termed day-neutral, is a commonly desired trait, particularly in photoperiodic, herbaceous ornamentals (Anderson, 2006).

Blue flowers. True blue flowers have driven a centuries-long quest by flower breeders to create such colors in flower crops where it does not exist. Burbank was no exception, creating blue roses (compare with color photograph, Burbank, 1914-15, vol. 9, p. 42-45), poppies, and tiger flower (Tigridia). Interspecific crosses started in the $1880 \mathrm{~s}$ with Tigridia pavonia, T. conchiflora, and $T$. buccifera (Burbank, 1914-15). Other Tigridia spp. would not cross with these hybrids so Burbank expanded to making intergenerics with the closely related genus Ferraria. He also tried, unsuccessfully, to make a triple intergeneric between these and Herbertia platensis. Nonetheless, the Tigridia interspecifics resulted in a unique blue-flowered 'Burbank' genotype discovered in 1894 and later released in 1914 (Fig. 21; Burbank, 1894) and 'Chilean Dwarf', released in 1920 (Burbank, 1920a). To the best of our knowledge, creation of such blue tiger flowers has not been achieved since.

Convenience. Numerous traits confer "convenience" to growers, retailers, and consumers and Burbank created many flower crops with sterility, heat/drought tolerance, dwarfism, free branching, and everblooming traits. His breeding and selection procedures also benefitted from implementation of convenience methodology, allowing him to concentrate breeding of numerous genera on the small Gold Ridge View Experiment Farm. Crossing of parents was often accomplished

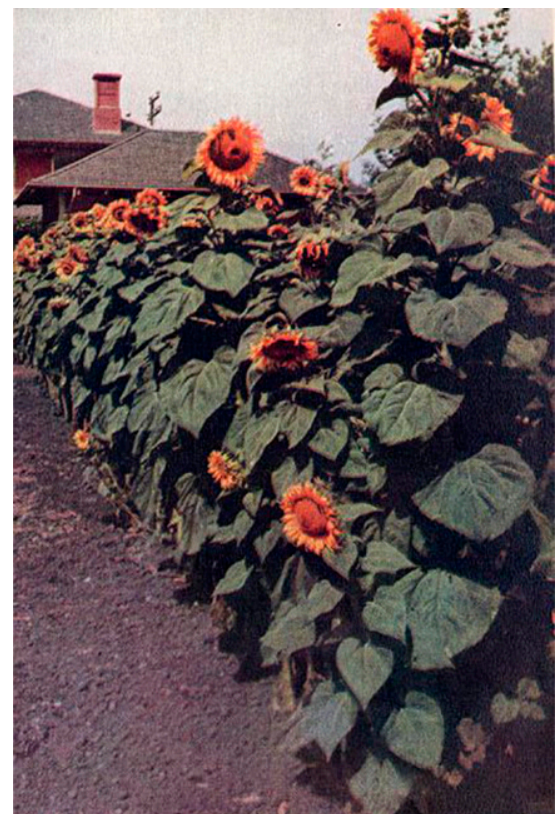

Fig. 17. Helianthus annuus hybrid breeding was completed with relative ease, since traits were "readily fixed" and came true from seedprovided one rogued out the off-types (Burbank, 1914-15).

in very tight plant spacing (Fig. 22A) as well as subsequent seedling and clonal hybrids in closer proximity than standard protocols ( $0.3 \mathrm{~m}$ on center). This space minimization for perennials requiring greater than 1 year to flower from seed efficiently created side-by-side flower color and type comparisons for ease in "reading" breeder trials such as Tulipa (Fig. 22B). As a result, the clearest and best colors could be readily selected in the same environment as well as determining the earliest and/or longest duration in flowering, heterotic or vigorous genotypes, disease or insect tolerance, etc. Such techniques are still implemented, particularly because space is a costly input in cultivar development for greenhouse, container, and field trials over years and locations (Anderson, 2006).

Fragrance. In addition to fragrance in lilies (discussed previously), the development of fragrant Verbena occurred twice in the history of Burbank's breeding efforts. Howard (1945) described this as his "chief attainment within the species," although, once again, the complete lack of breeding records meant that no subsequent verbena breeder could repeat his exact crossing scheme. 'Mayflower' was a fragrant verbena released in both 1895 and 1901 (Fig. 23; Table 1), along with 'Fragrance', 'Giant Mayflower', and 'Mayflower Pink' (Table 1). 'Mayflower' was at first clonally propagated, because it did not come true from seed, although the distributor, John Lewis Childs, reported slow cutting production that could not keep up with demand (Burbank, 1918a; Howard, 1945); this was later introduced as a seed product by 1899 (Fig. 23). Burbank later developed another race of fragrant verbena, 'Fragrance' (Table 1), which he released in 1901 and distributed as 


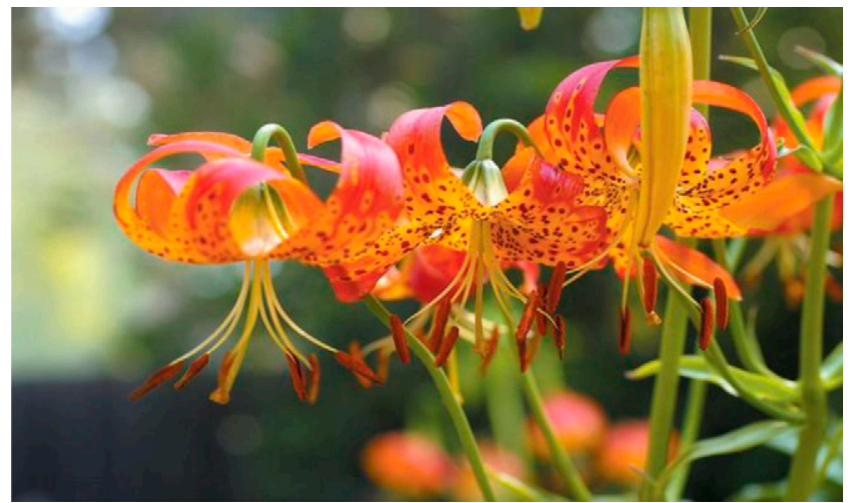

Fig. 18. Breeding with North American natives: triple hybrid Lilium, L. parryii $\times$ L. washingtonianum $\times L$. pardalinum progenies ranged from 18 inches to 8 feet in height with fragrance that could be distinguished miles away (Burbank, 1914-15).

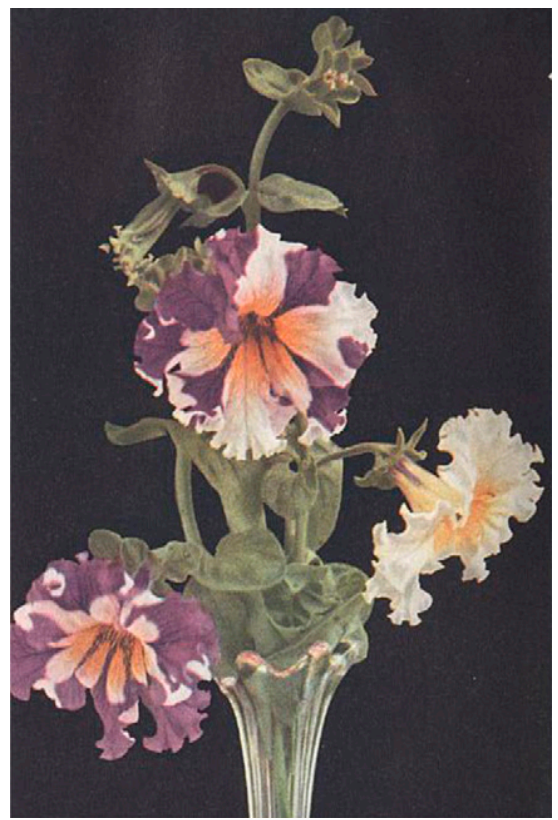

Fig. 19. 'Nicotunia', an "interesting failure" with the first vegetative Petunia derived from the Intergeneric cross Nicotiana wigandioides rubra $\times$ Petunia hybrida var. grandiflora (Burbank, 1914-15).

'New Fragrance' by Conrad and Jones Company (West Grove, PA); the Burbank Company sold it later in 1913.

Calla lily $($ Zantedeschia; $=$ Richardia $)$ is another example crop bred for fragrance. At first, Burbank concentrated on variegated foliage and dwarfism ("Variegated Little Gem' was released in 1893; Table 1). Later, however, he focused calla breeding objectives to fragrance in interspecific Zantedeschia and released three such cultivars, e.g., 'Burbank's Scented' (Fig. 24A), 'Lemon Giant' (Fig. 24B), and 'Dwarf Scented' (Table 1; Burbank, 1914-15). For the most part, scented callas have disappeared completely from the floriculture market.

Ornamental vegetables. Luther pioneered efforts to breed ornamental vegetables such as corn and teosinte, pink chives, tomatoes, and spineless cacti (Burbank, 1914-15). This
A

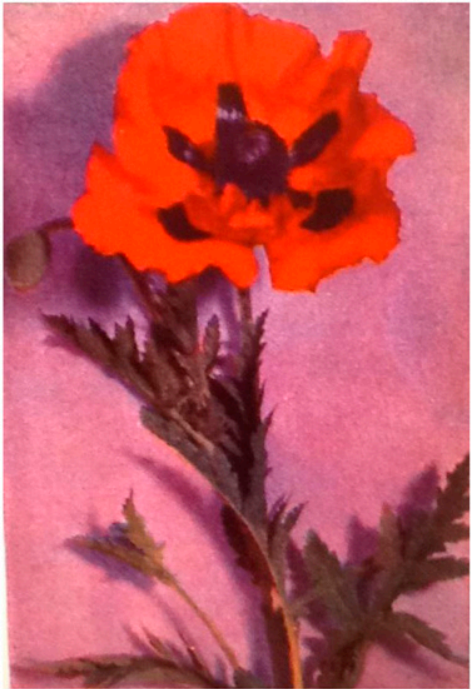

B

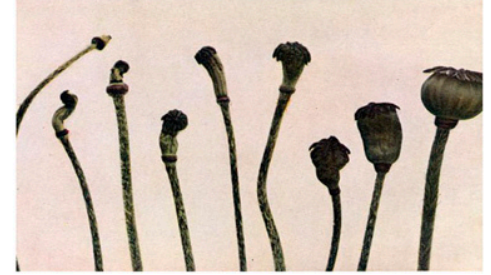

Fig. 20. Flowers (A) on an everblooming, sterile, and interspecific poppy, derived from crossing annual and perennial species, Papaver somniferum $\times P$. orientale. (B) Sterile (left) and rudimentary fruit (right) (Burbank, 1914-15).

is still a popular trend for flower breeders across the globe. Burbank's corn breeding started in 1870 focusing on sweet, edible types. In 1908, he began breeding ornamental corn by first selecting two "quadri-colored" stalks in an ornamental seed lot from Germany, which he proposed had originated from a cross between a green-leafed type and Japanese variegated corn (Zea mays variegata; Burbank, 1914-15). By several generations of selection later, Burbank had six colors of stripes in the leaves. 'Rainbow' was one such cultivar (Fig. 25). 'Rainbow' generated considerable publicity for Burbank as a result of the rarity of six stripe colors. He later released 'Aurora',

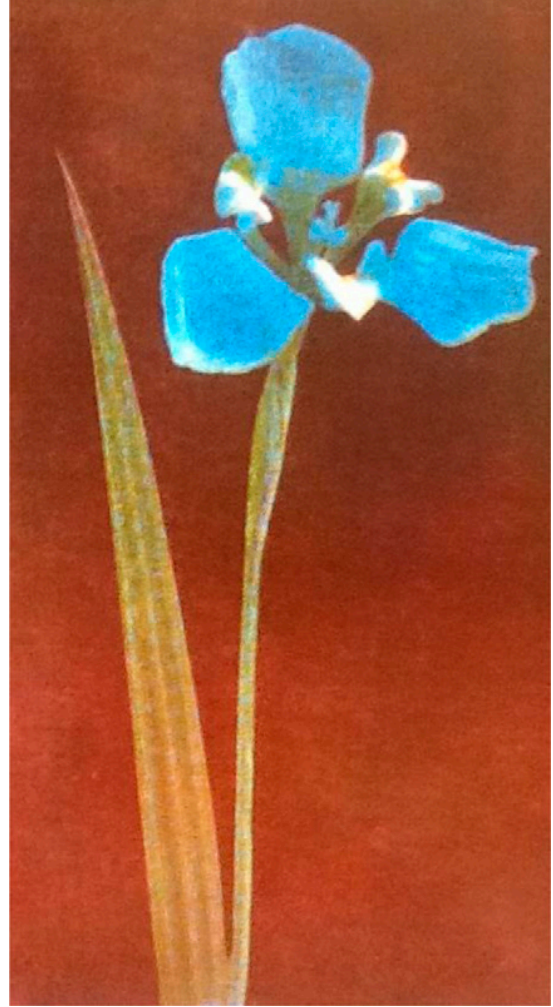

Fig. 21. Interspecific Tigridia hybrid 'Burbank' sporting a blue flower (Burbank, 1914-15) Such a hybrid has never been repeated. Burbank also released a blue Herbertia pulchella, that looked similar.

a new and improved form of 'Rainbow' (Table 1). Rainbow-type corn is still on the market, although Burbank is not given any credit in their development. Burbank's breeding efforts in chard (Beta vulgaris ssp. vulgaris), although at the time not directed at ornamental features specifically, did result in the introduction of 'New Rainbow' with leaves of "mingling iridescent rainbow shades" (Howard, 1945), a precursor to the modern use of ornamental chard in cool-season bedding plant schemes.

Species named after Burbank. Flower breeders rarely have the opportunity to have plant species named after them because that is reserved for botanists and plant collectors finding new species in the wild. However, the wide interspecific hybrids created by Luther Burbank allowed this in four divergent families (Burbank, 1914-15). Chrysanthemum $\times$ burbankii Makinoi (Asteraceae) is a white, single daisy hybrid (Fig. 26A) that was not used in the creation of the shasta daisy hybrids. Lilium $\times$ burbankii (Liliaceae) is a Turk's cap lily created from crossing the North American L. pardalinum $\times L$. parryii (Fig. 26B). Another interspecific hybrid in the Solanaceae is named for Burbank and remains on the market today, i.e., Solanum $\times$ burbankii Bitter (Fig. 26C). This was derived from the cross $S$. villosum $\times S$. guineense and was originally named 'Sunberry' by Burbank but sold by John Lewis Childs as 'Wonderberry'; this cultivar name continues to this day (Fig. 26D). The fourth 
Burbank species is still under considerable taxonomic dispute: Myrica $\times$ burbankii A. Chev. (Myricaceae) was based on Burbank's claim to have crossed $M$. cerifera $\times M$. californica; no photographs of this species are available.

The shasta daisy. Burbank's most popular ornamental release, the shasta daisy hybrids
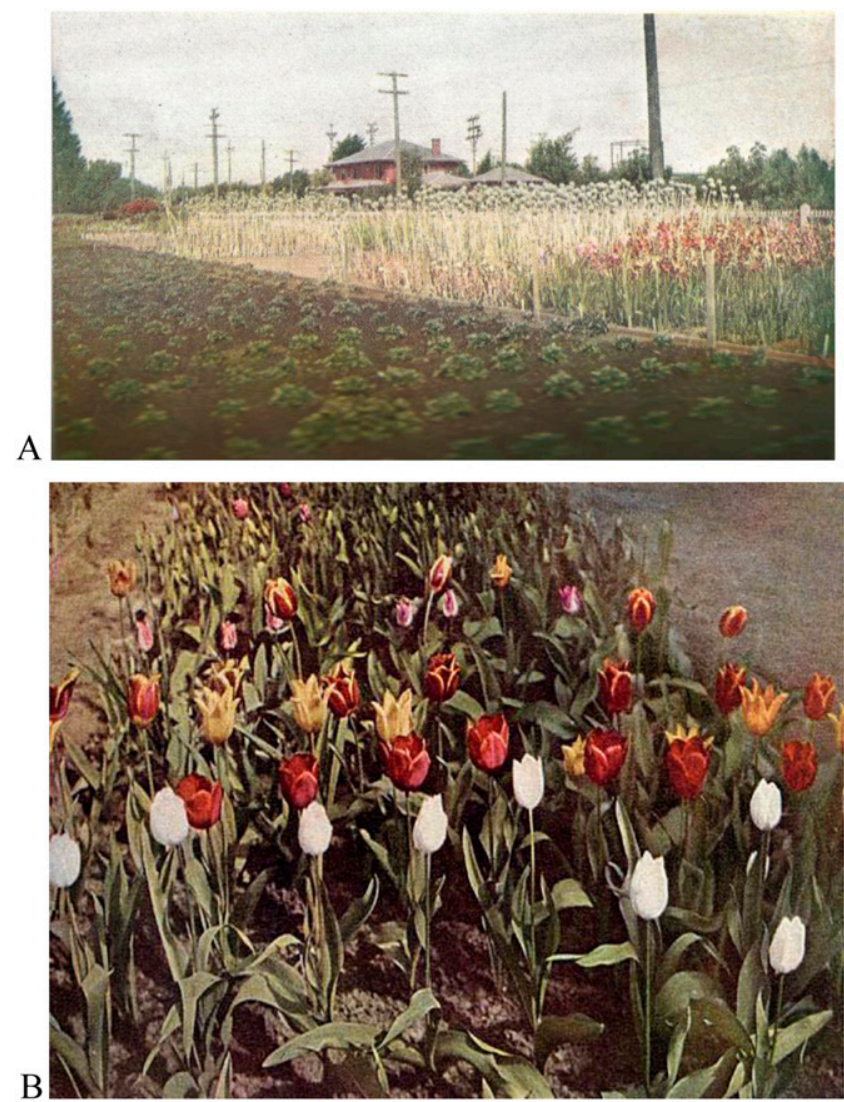

Fig. 22. "Many plants in small spaces" demonstrating the (A) tightly spaced crossing setups that Burbank often used and (B) subsequent clones or seedlings of variations (Tulipa) efficiently planted close together for ease of selection once they came into flower (Burbank, 1914-15).
(Leucanthemum $\times$ superbum), remains to this day a significant flowering perennial on the global market with upward of 170 cultivars available (Hatch, 2013), including the original 'Alaska' (Burbank, 1904) (Fig. 27; Table 1). The shasta daisy hybrids were first released in 1901 as "Chrysanthemum leucantheumum hybridum," a complex hybrid strain of four species of chrysanthemum as Burbank knew them at the time: Chrysanthemum leucanthemum, C. lacustre, $C$. maximum, and C. nipponicum (= Leucanthemum vulgare, L. lacustre, L. maximum, and Nipponathemum nipponicum, respectively) (Fig. 28). The story, as countlessly retold by Burbank, begins with his childhood fascination with the common European oxeye daisy ( $L$. vulgare) that was naturalized in his New England childhood home in Lancaster, MA, and which possessed the common white ray florets and yellow disc florets that make up the flower head in this section of the Asteraceae. On starting his business in California, Burbank imported this species and began in 1884 to work in earnest on enhancing the flower size (ray florets) within the species. $\mathrm{He}$ first sought, as he did with many other crops, to improve the species through mass selection of OP seed. Unsatisfied with the results, Burbank crossed his best selections with the "English daisy," probably L. maximum, a species with larger but coarser flower heads than L. vulgare (Hall, 1939). These hybrids, although improved over the parental species, were "too rank for beauty, a tendency to run too much to foliage, and finally a blossom that left too much to be desired in purity and waxiness" (Hall, 1939). To rectify this, Burbank next crossed the best advanced hybrids with the Portuguese oxeye daisy, L. lacustre (Fig. 28 ), and further refined his hybrids over five or six generations; however, he was still

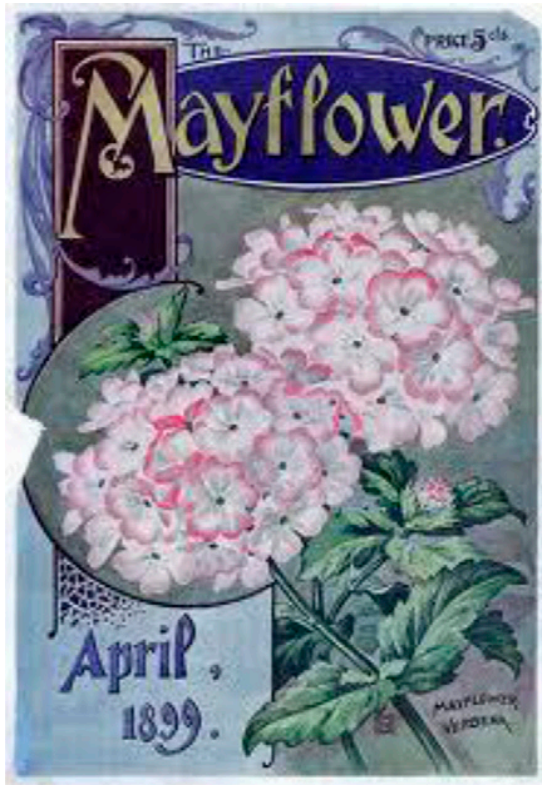

Fig. 23. Seed packet of 'Mayflower' fragrant Verbena hybrid offered for sale in 1899 (Burbank, 1899).
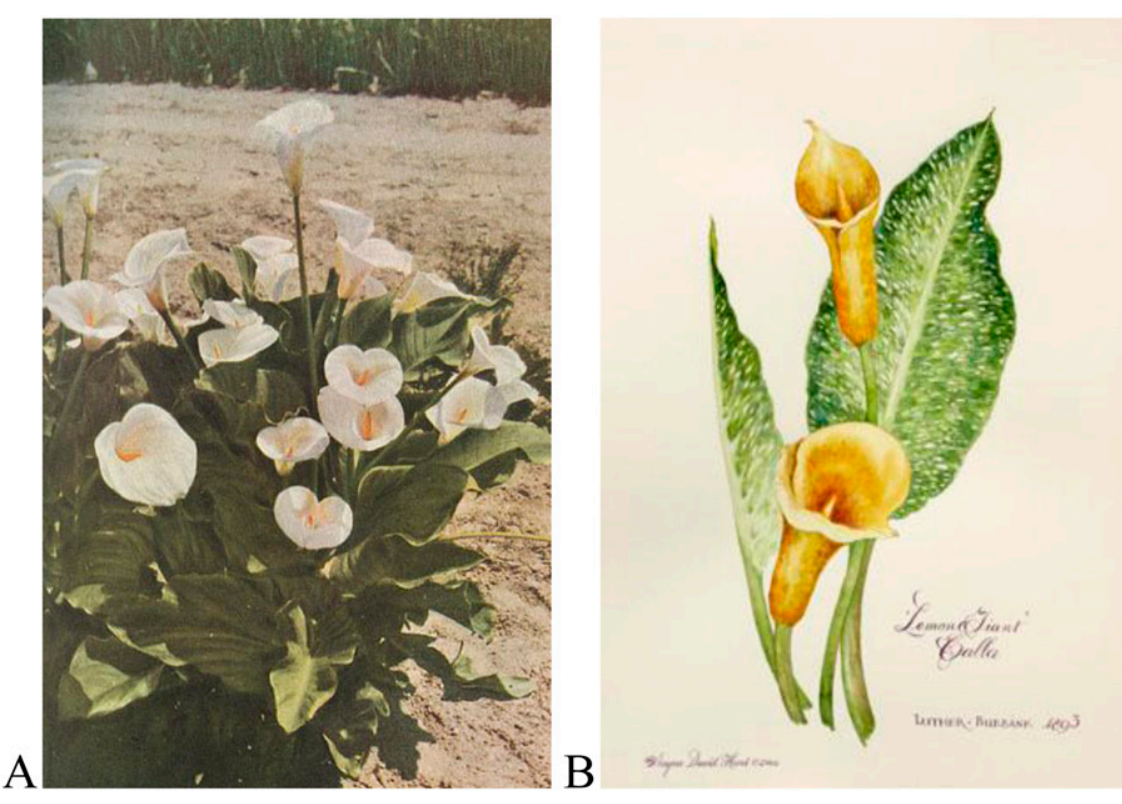

Fig. 24. Fragrant Zantedeschia (= Richardia) 'Burbank's Scented' (A) and 'Lemon Giant' (B) (Burbank, 1914-15). 
unsatisfied with the whiteness of the ray florets (Hornback, 1982; Howard, 1945).

Burbank was told of a Japanese species of oxeye daisy (Nipponanthemum nipponicum) that possessed "small and inconspicuous" flowers but with "a pure waxy white color" (Hall, 1939). He insourced seed from Japan and made repeated attempts over five or six seasons (Howard, 1945), finally selecting a single plant that combined all the desired flowering characteristics and habits he sought. From this he raised an additional five or six generations of seedlings, selecting for seed-bearing as well as adaptability, precocious flowering, and large flowers on leafless stems (Hall, 1939). In 1901, Burbank

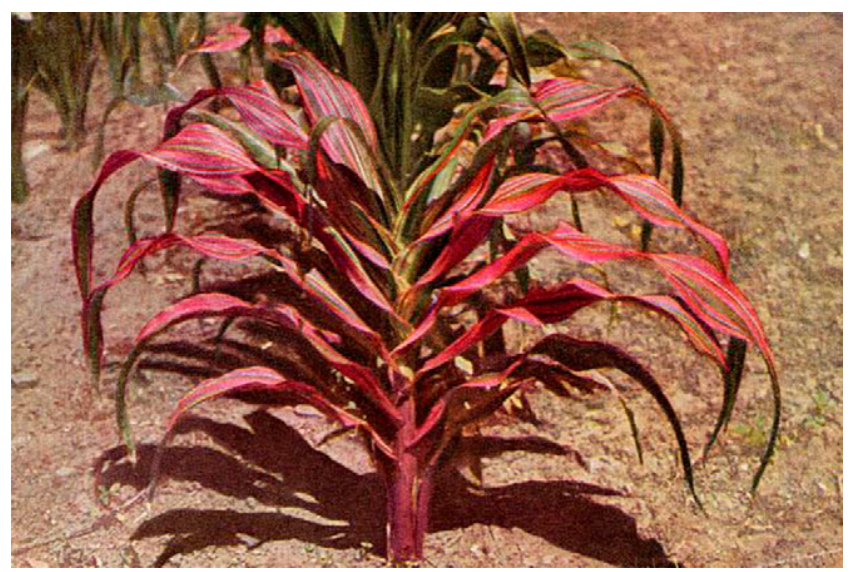

Fig. 25. Ornamental vegetable example, Zea mays 'Rainbow' (Burbank, 1914-15). introduced his "Shasta Daisies" (Table 1; Fig. 28), named after the eponymous snowcapped California mountain nearby.

The number of species used to create shasta daisies, often described by Burbank as three (L. vulgare, L. maximum, and $N$. nipponicum) (De Vries, 1907; Hall, 1939) or four with the addition of L. lacustre (Fig. 28) (Hornback, 1982; Howard, 1945) may be debated; however, their hybrid nature is not. Botanists and horticulturists have ascribed the shasta daisies to the cultivated hybrid $L$. Xsuperbum, a hybrid between L. lacustre and L. maximum (Kent, 1990). Leucanthemum maximum, a true species from the Pyrenees, has apparently been rarely cultivated in the United States with most forms assigned to this species (e.g., L. maximum "of gardens") really attributed to the hybrid, $L$. Xsuperbum (Ingram, 1975). The hybrid species, along with the common species L. vulgare, are naturalized in California (Hickman, 1993) and, taken together, may give credence to the belief that Burbank simply improved on the naturalized form of $L . \times$ superbum found in California (De Vries, 1905; Howard, 1945). The confusion persists to this day in horticulture with the recent proposal of grouping cultivated forms of shasta daisy under the
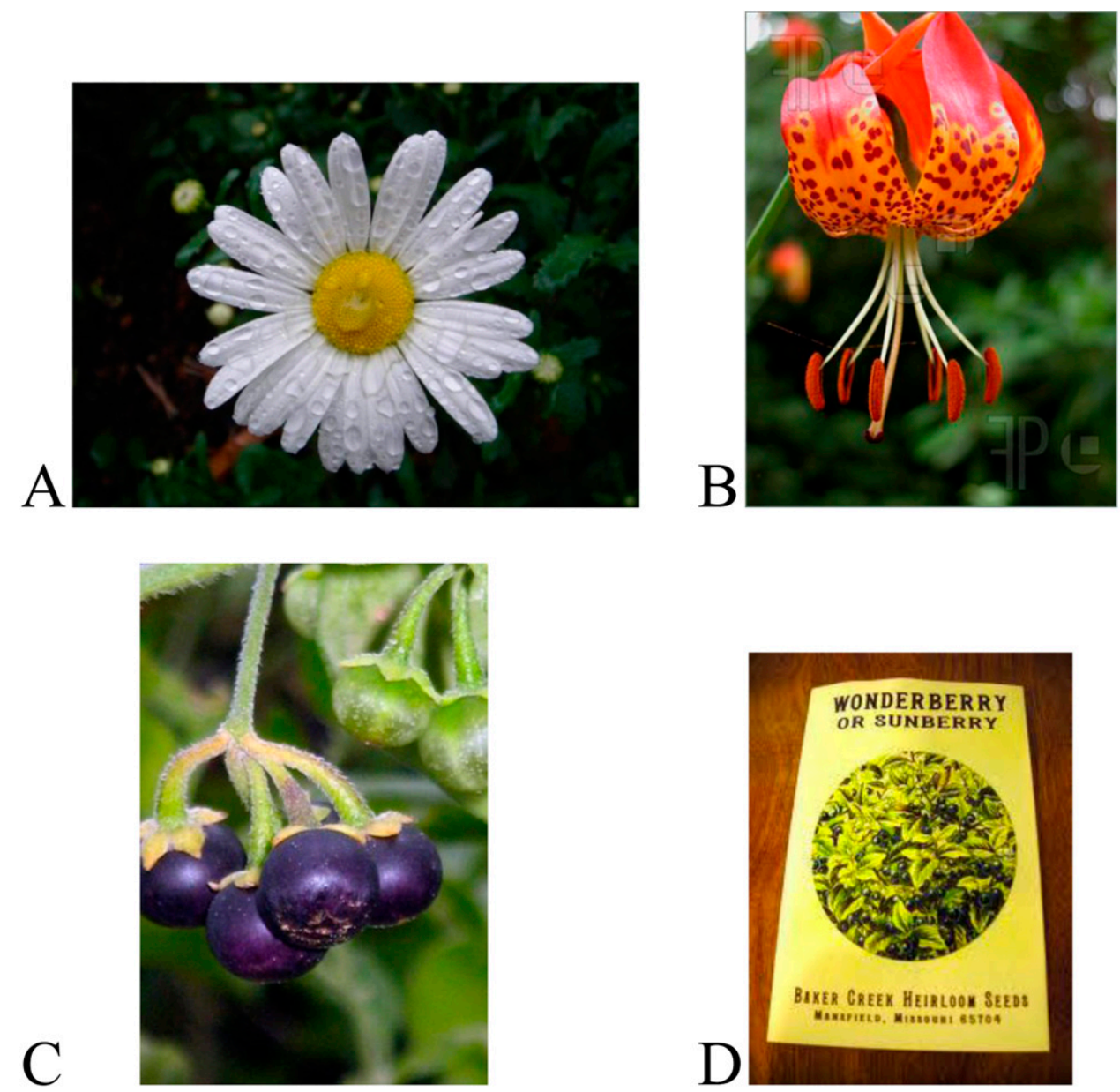

Fig. 26. Three of the four flowering plant species named after Luther Burbank include: (A) Chrysanthemum $\times$ burbankii Makinoi (Asteraceae), (B) Lilium $\times$ burbankii (L. pardalinum $\times$ L. parryii), (C) Solanum $\times$ burbankii Bitter $(S$. villosum $\times$ S. guineense), which was $($ D) introduced by John Lewis Childs as 'Wonderberry' (Burbank, 1914-15). 

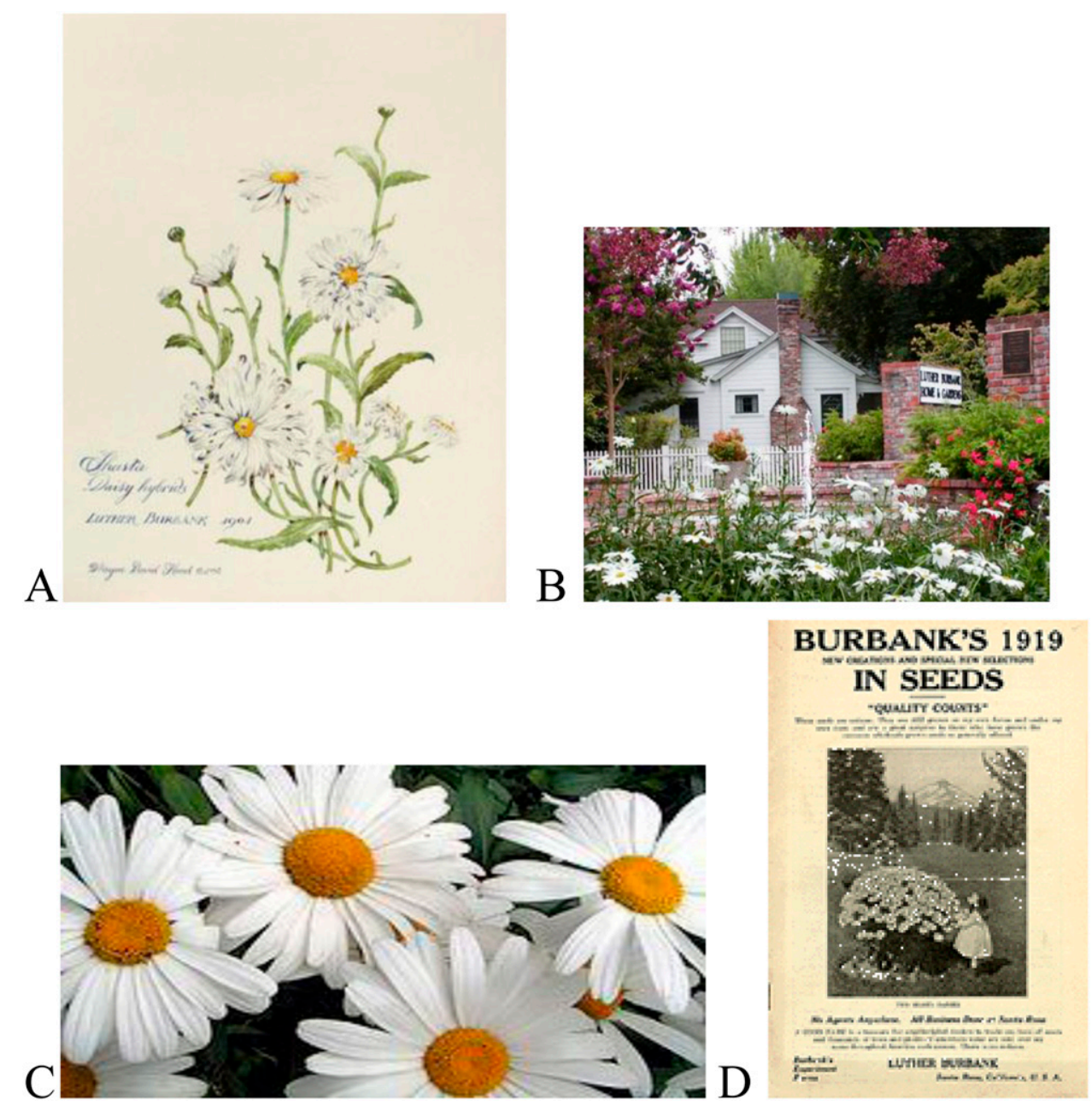

Fig. 27. The creation of the first 'Shasta Daisy' hybrids (A) in 1901, (B) descendents still flowering outside of Luther Burbank's home in Santa Rosa, CA, (C) a closeup of the single-duplex daisy flowers with white ray florets (petals) and central yellow, disk florets, (D) an early 1919 advertisement of 'Shasta Daisy' was on the front cover of Burbank Seeds catalog (Burbank, 1919).

Leucanthemum Maximum Group, which would encompass the former Chrysanthemum $\times$ superbum and C. maximum cultivars and some cultivars of the parental species (Hatch, 2013).

Regardless of parentage, the "Shasta Daisies" as a group are of significant value to the ornamental nursery industry, as evidenced by a recent plant evaluation of 36 cultivars for northern gardens performed at the Chicago Botanic Garden (Hawke, 2007). Burbank continued to release cultivars up until the year before his death; the first three selections, 'Alaska', 'California', and 'Westralia', were introduced in 1904 (Table 1; Burbank, 1904) as clonal selections propagated through root cuttings. In subsequent breeding efforts, Burbank selected forms with even larger flowers ('Shasta Giant'), double or fluted florets ('Double Fluted Shasta'), serrated florets, and cream to yellow ray florets (Fig. 29; Table 1) (Hall, 1939; Howard, 1945). All are prolific producers of cut flowers, as exemplified by the rows of shastas grown in 1912 for the National Federation of Women's Clubs (Fig. 30). Today's plant breeders are building on Burbank's initial breakthroughs, best exemplified by the Realflor Collection of $L$. ×superbum offered by PlantHaven International, Inc. (Santa Barbara, CA), which includes cultivars with yellow ray florets ('Real Dream'), fringed florets ('Real Galaxy'), anemone-flowered forms ('Real Glory'), and fluted florets ('Real Neat').

"The spineless opuntia: an established fact." Cacti were another area of selection and breeding by Burbank. He released a few flowering ornamental types such as Opuntia basilaris, Cereus chilensis, and Echinopsis mulleri (Table 1). However, most of his work concentrated on spineless forage types. Although Burbank's shasta daisies represent a lasting success, his spineless prickly pear (Opuntia subgenus Opuntia, Cactaceae) project, although not an abject failure, encapsulates at once the shortcomings of his methods and the fine line between noble vs. financial pursuits in plant improvement. The rise and fall of Burbank's spineless Opuntia introductions has been well covered by Smith (2010) and to some degree in Benson (1982). In short, Burbank fell prey to both his own legend and the media hype that surrounded him, which posited him in the upper echelon of innovators at the beginning of the 20th century and the center of speculative and unscrupulous business ventures seeking to profit from this fame and, ultimately, led to a very public clash and crash because the market and taste for prickly pears never materialized.

Cacti were a major focus of Burbank, specifically the improvement of prickly pears, which he saw as the ideal solution for crop-poor marginal agricultural land in the arid regions of the world. Burbank was introduced to spineless Opuntia sometime after arriving in California, where spineless forms of the Indian fig (O. ficus-indica), like 'Marin', had already been introduced and cultivated (Burbank, 1907; Griffiths, 1912, 1928). "Spineless" is a relative term, referring to the true spines (modified leaves) and the minute glochids ("spikules" or modified, barbed hairs) born in areoles (modified axillary buds) in Opuntia (Fig. 31A) (Benson, 1982). Essentially spineless forms were already known, mostly forms of the widely cultivated $O$. ficus-indica, which originated in central Mexico and were disseminated by the Spanish for use in climatically suitable areas of their empire (Griffith, 2004; Russell and Felker, 1987). The cultivation of Opuntia and several other genera of cactus by indigenous peoples in the Americas predated the arrival of the Spanish, where it was grown 


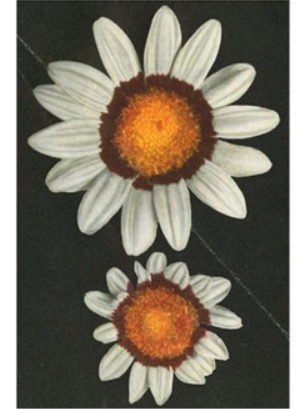

Leucanthemum vulgare N. England Oxeye Daisy

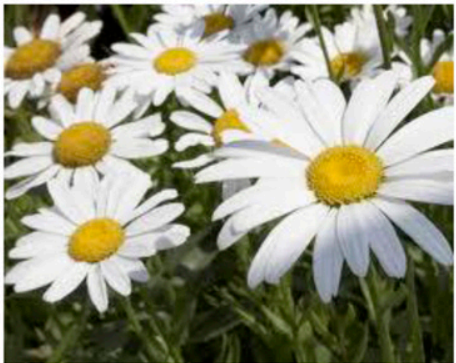

Leucanthemum maximum

English field daisy

F1 x Leucanthemum lacustre, Portuguese field daisy 6 years of breeding/selecting

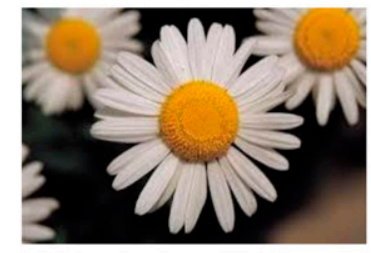

F6 x Nipponanthemum nipponicum, Japanese field daisy

'Shasta' (first created in 1901)
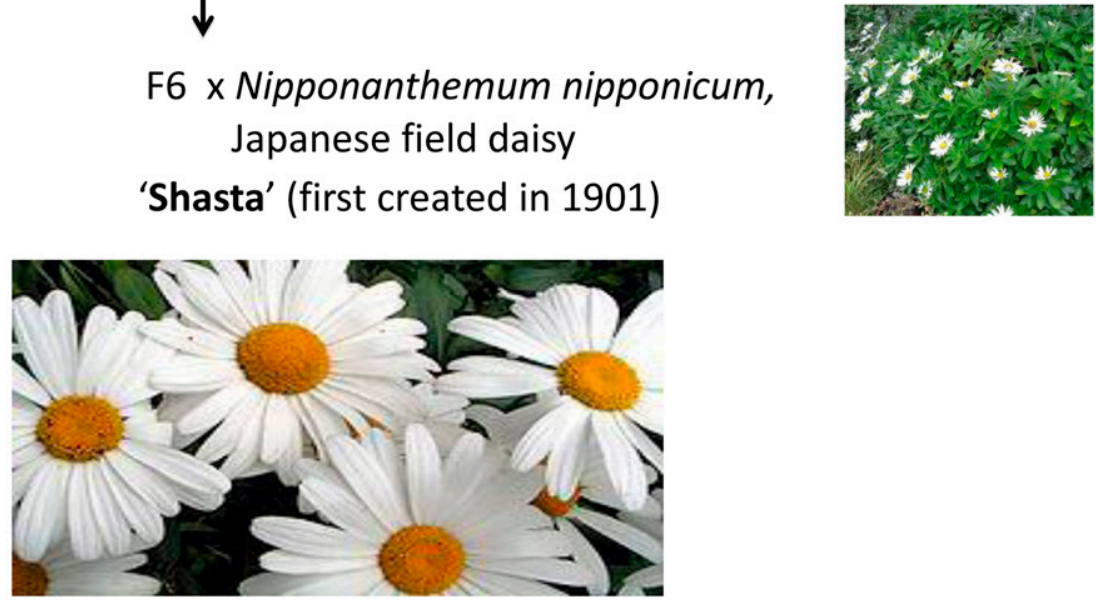

Fig. 28. The evolution of 'Shasta Daisy', named after Mount Shasta, located nearby the Sebastopol Farm (Burbank, 1914-15).

for both its edible fruit (tuna) and pads (nopales) as well as for other economic uses, like the important cochineal dye industry (Benson, 1982; Russell and Felker, 1987). By the end of the 19th century, prickly pear cultivation for agronomic and industrial use was established in most of the arid regions of the world, including the Mediterranean, northern and southern Africa, India, and Australia (Burbank, 1907; Griffiths, 1912, 1928; Russell and Felker, 1987).

The use of prickly pear as a forage crop began with the introduction of cattle to the New World by the Spanish to their territories in Mexico and the southwestern United States where Opuntia and their relatives are native. David Griffiths, an agrostologist or grass researcher within the Range Investigations Unit of the Bureau of Plant Industry at the USDA, published the results of massive surveys in this region on the extent of Opuntia forage or fodder use by ranchers (Griffiths, $1905,1912,1928)$. Forage and fodder use was documented in all regions where cattle and prickly pears overlapped, from southern $\mathrm{Cal}$ ifornia to Colorado and down through Texas, where the most extensive use of Opuntia was recorded. In general, the native prickly pears were prepared for foraging by removal of the main spines, either through singeing with brush fires or special "pear-burners," then chopped with machetes for direct foraging or through special "pear handling machinery" for fodder production (Griffiths, 1905). Here Burbank saw an opportunity to apply his breeding prowess toward generating a new race of "spineless" Opuntia that required no pre-processing to remove spines and yielded more tonnage in pads and fruit per acre with greater adaptability (Burbank, 1907). For example, 'Melrose' (Table 1) was one cultivar Burbank released that after less than 4 years from transplanting was estimated to produce $1 \mathrm{t}$ fresh weight/day (Fig. 32).

Burbank's foray into cactus breeding began in the mid-1890s, when he began amassing a germplasm collection of cacti, including the native, hardy forms of the southwestern United States as well as the cultivated "spineless" forms already in cultivation, like 'Smith' (north Africa, 1893; from E.E. Smith), 'Skelley' (Sicily, 1895: from E.R. Skelley), and the aforementioned 'Marin' (may have been introduced as 'Marine' by Don Francisco de Paula Marin, ₹1791; Table 1) (Burbank, 1907). Burbank augmented his collection with those of the USDA's PI program, which beginning in 1898, started to collect both fruiting and forage types from around the world. In 1899, David Fairchild and W.T. Swingle with the USDA procured or collected many cultivated and wild forms from the Mediterranean and South America, including PIs 3422 and 3423, spineless forms from Argentina that Fairchild recommended to "be used in cross-breeding with other prickly pears." Burbank was not satisfied with these forms of "spineless" Opuntia, because they produced 

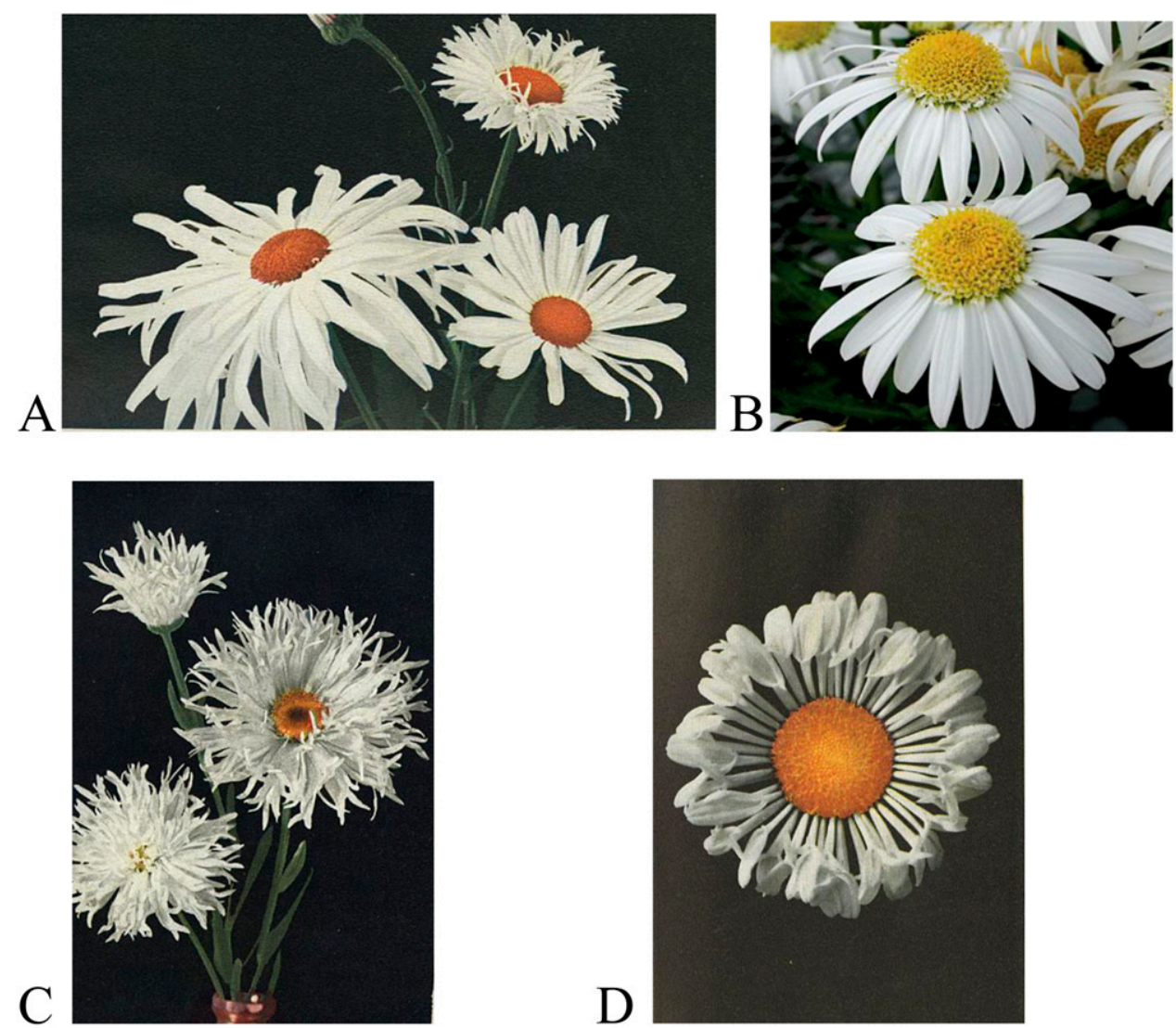

Fig. 29. Example flower types of 'Shasta Daisy' created by Burbank's interspecific hybridizations: (A) single or simplex daisy (lower right), duplex daisy with long ray petals (lower left), and fringed types (upper right); (B) Anemone flower type in a simplex daisy; (C) fringed petal types; (D) spoon single daisy type (Burbank, 1914-15).

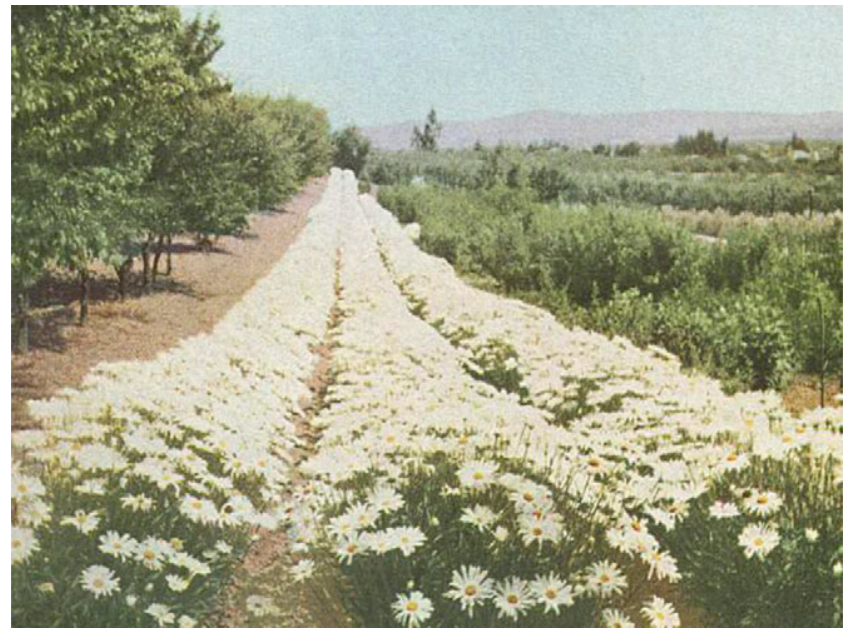

Fig. 30. Rows of 'Shasta Daisy' growing on the Sebastopol Farm, 1912, grown for the National Federation of Women's Clubs Meeting, San Francisco, CA (Burbank, 1914-15).

little to no spines or glochids, but rarely both, and Burbank sought a "perfectly" spineless form. However, in Burbank's initial offering of 19 new and improved Opuntia (1907; Table 1), seven were USDA PIs (e.g., 'Anacantha') and several more were likely the same germplasm independently obtained by Burbank from Walter Bryant ('Blanco', 'Morada'), Don Francisco de Paula Marin ('Marin'), and Frank Meyers ('Meyers') (Table 1).
Interestingly, eight of these existing cultivars were being sold as the best, despite not having set fruit for him, so determinations as to quality were not based on his first-hand observations. In the same catalog, Burbank introduces the first of his completely novel introductions, consisting of seven cultivars and two hybrid mixes. 'Santa Rosa' (Table 1), an Indian fig type, was apparently the star of the class with "no thorns and no bristles.
The first of its kind...” (Burbank, 1907) (Fig. 31B). Again, the rapid pace of introduction by Burbank can be seen, because the new clones were only 3 years old from seed and had not produced fruit, but based on their initial habit and spinelessness, were released. These and other selections later fruited (Fig. 31C), allowing Burbank to evaluate flavor in fresh and preserved fruits.

Collecting OP seed from his cacti germplasm and making crosses between nearly spineless types created immense populations for mass selection of spineless types (lacking both spines and glochids) at early stages of development of seedling development. He created a meticulous seedling screening method to undertake selection in the "true leaf" or pad stage after the cotyledonary stage (cotyledons are usually $100 \%$ spineless). He often sowed the large seeds individually (singulation) in wooden flats, which, after germination, percent germination and initial screening could begin (Fig. 33). Seeds were planted in a $10 \times 10$-row/column grid systems using a dibble board, which resulted in a flat of individual seedlings in a "plug tray" configuration of 100 seedlings (or a 100-plug tray). Such regular planting instead of in-row flats made for easier transplanting, screening for spinelessness in seedling Stages II to IV (McDonald, 1999) and is the configuration later used in modern 10 inch $\times 20$-inch plug trays after the plastics 

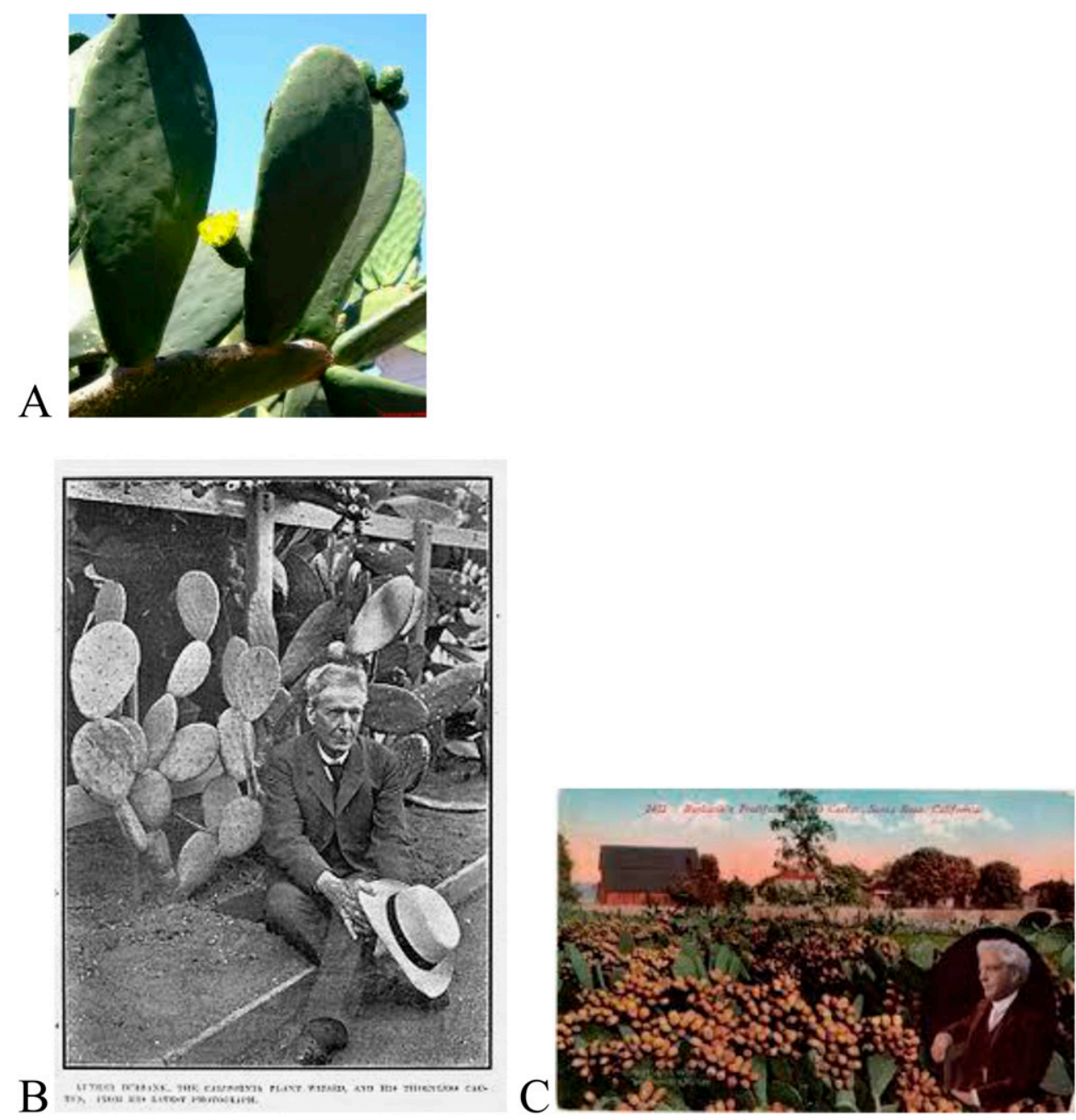

Fig. 31. The spineless cactus (Opuntia): 15 years of breeding and selection to produce nearly and/or completely spineless forms (Burbank, 1914-15). (A) A closeup of the flowers, fruit, and spineless pads (Note: the recessed nodes on each pad from whence spines would normally be produced). (B) Burbank sitting near an early accession with reduced frequency of spines, most likely 'Santa Rosa', and (C) a Luther Burbank postcard displaying the fruits on a field of spineless cacti.

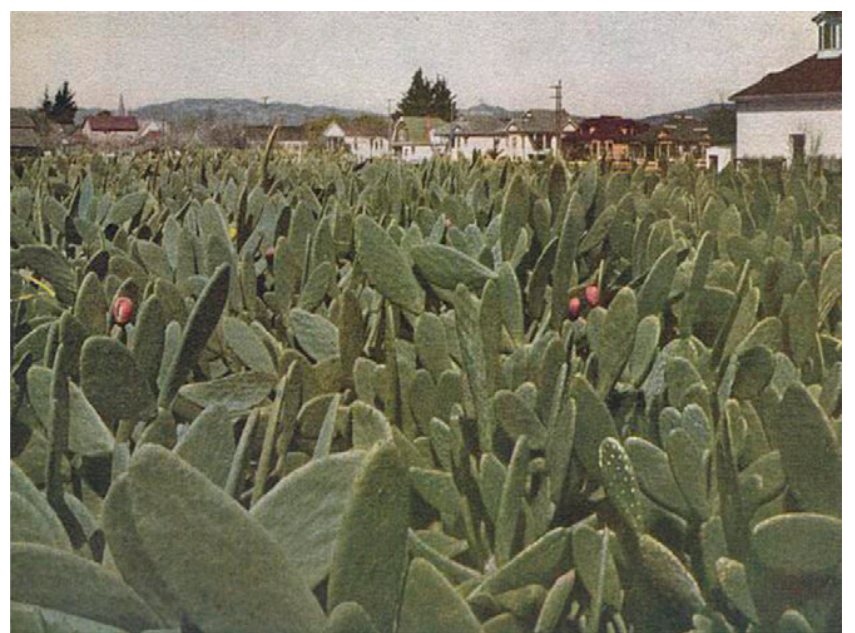

Fig. 32. Spineless cactus 'Melrose' growth in less than 4 years from transplanting of rooted pads. Luther Burbank estimated that 'Melrose' produced $1 \mathrm{t}$ weight/day in June (Burbank, 1914-15).

revolution in the 1980s (Konjoian, 1999). When he had larger populations, they were often broadcast sown in outdoor coldframes (Fig. 34A).
Although modern-day breeders easily select in plug trays for high germination $(\%)$ and yield potential (percent of transplantable seedlings), Burbank selected strictly for spinelessness. This phenotypic selection would closely match what is done by commercial stock (Matthiola incana) producer firms and/or pre-finisher growers by growing seedling flats at high temperature $\left(4.4^{\circ} \mathrm{C}\right)$ for 1 week after radicle emergence to rogue out undesirable single-flowered types (dark green cotyledons) in double-flowered (pale green cotyledons) hybrid seed (Takii Seed Company, 2014). After rogueing out spined seedlings, the remaining spineless types could be left to grow for greater than 1 year to select for competitive (vigorous) "giant" seedlings among "dwarf" types (Fig. 34B). In Years 2 to 3, seedlings and/or vegetative pads were transplanted into long rows for subsequent evaluations (Fig. 34C). Rogueing continued in this phase, a rather precarious job balancing on a board above the primary spineless seedlings (Fig. 34D)!

Like the majority of his introductions, ornamental or otherwise (Table 1), Burbank provides little to no parentage information, invariably using the terms "selected hybrid," "crossbred," "developed", or, once, "secondgeneration" to describe their origins (Burbank, 


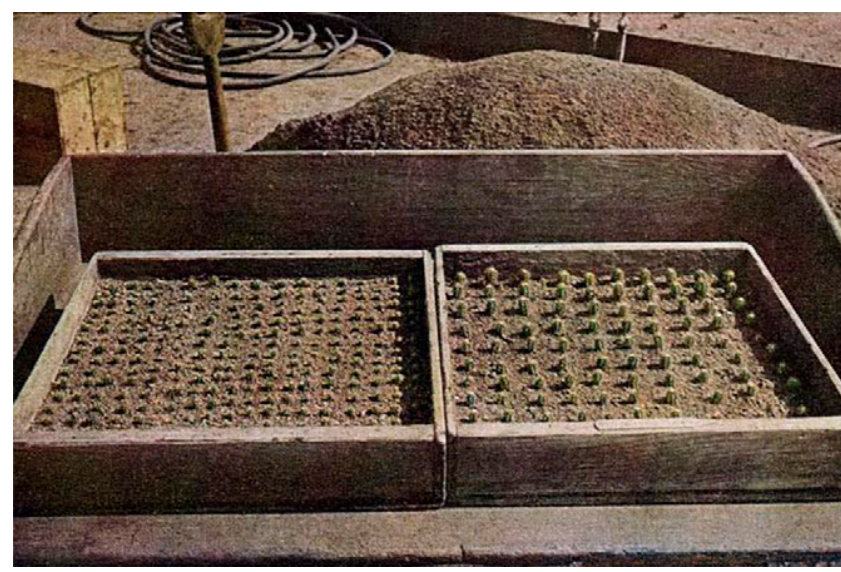

Fig. 33. Stages I to II of cactus seedling germination. Seeds were either sown spaced out as shown (left) to subsequently grow, appearing as modern-day "plug trays" of seedlings! Screening for lack of spine production could be accomplished at this early phase (Burbank, 1914-15).

1907; Howard, 1945). Of the $\approx 63$ cactus introductions attributed to Burbank (Table 1), at least 18 are seedlings or clones of germplasm assembled from his contacts, like 'Smith', named for E.E. Smith who collected it in north Africa in 1893, and 'Anacantha' PI 3423 introduced by Fairchild and Lathrop from $\mathrm{La}$ Plata, Argentina, in 1899 (Table 1). Both cultivars happen to be the most frequently mentioned parents in Burbank's hybrids. Only six introductions have both parents listed such as 'Actual' ('Anacantha' $\times$ 'Smith'), whereas another seven are described as hybrids but with no pedigree information (e.g., 'Fresno'). Eight of Burbank's introductions appear to be OP seedlings (e.g., 'Banana' and 'El Dorado' derived from 'White Fruit'), whereas the remaining 24 are of unknown origin, including 'Burbank Standard', introduced in 1911 (Table 1), as the product of 14 years of breeding (Howard, 1945).

In simple terms, Burbank was a thrifty and savvy plant breeder-nurseryman-businessman, assembling the best germplasm, growing out large numbers for evaluating, and selecting the best to breed the next generation while selling off the surplus stock. After the initial offering in 1907, when 27 varieties were introduced (Table 1), two-thirds of which were germplasm, the remainder of his introductions was presumably hybrids or selections thereof. From 1909 to 1925, Burbank introduced 30 more selections, which coincided with the peak of the "great cactus boom and bust" at the start of the 20th century (Table 1) (Benson, 1982).

Burbank was not the first to recognize the potential of spineless cacti, although he was likely the most personally invested. According to Burbank, there were numerous spineless cactus qualities that would make this an outstanding forage (animal), food (humans), and industrial crop (Burbank, 1907, 1914-15):

\section{"Supply abundant quantities of fresh fruit which ship excellently (eaten fresh or as jams, jellies, juices);}

Slabs supply an unprecedented amount of forage for stock and poultry;
Young slabs make excellent pickles, good....when fried like eggplant, ... also boiled and used as greens; may be prepared with sugar to produce a sweetmeat ...like citron;

Leaves used... as poultices;

Abundant plant juices contain a mucilaginous substance that is used to fix pigments;

Thorny varieties are used as hedges to protect the thornless types;

Fiber of the plant makes an admirable stock for the manufacture of paper;

\section{Adaptability to arid regions.'}

At the turn of the 20th century, the USDA, encouraged by reports of prickly pear use as forage and fodder in the southwestern United States, began a systematic investigation of the extent of use and potential of Opuntia for regular stock raising (Griffiths, 1905, 1912, 1913, 1928). Griffiths' publications bolstered, at first, the potential contributions a spineless Opuntia would make to ranchers and farmers in the southwestern United States. By 1912, Griffiths had overseen a massive distribution of spineless forms to 2000 interested farmers (Griffiths, 1912). The distribution program by the USDA, combined with Griffith's less than favorable statements (backed up with data) that no spineless forms, not even the ones sold by "nurserymen" (e.g., Burbank), are "perfectly so" and that it "is improbable that any of the spineless forms if completely neglected would succeed under conditions prevailing in this country" (Griffiths, 1912) was an attack on Burbank's brand. Ultimately, Griffiths concluded that the future of prickly pear as a forage crop lay in the encouragement of maintaining the native, spiny forms for use in times of drought with the spines removed when needed; otherwise, planting and protecting spineless forms from browsing until needed were rarely justified (Griffiths, 1928).

Unfortunately for stakeholders and ranchers, the USDA reports were too late to prevent the spineless cacti bubble. Beginning in 1905, speculation on the financial windfall resulting from development of another new agricultural crop for California and the rest of the world began with John Rutland's (Australia) purchase of one 'Santa Rosa' pad for a $\$ 1000$ (Burbank, 1907). He paid less for 'Chico', 'California', 'Fresno', and 'Sonoma' (Table 1) and purchased the privilege of selling these in the southern hemisphere. To the best of our knowledge, this is the first example of exclusivity for ornamental crops in particular areas of the globe. Later, Burbank sued an express company for $\$ 10,000$ for a shipment lost in transit to Australia. The Thornless Cactus Farming Company of Los Angeles formed in 1907 and purchased the rights to sell all seven of Burbank's new spineless Opuntia for the staggering sum of $\$ 27,000$ (Smith, 2010). Railroad companies saw an opportunity to plant the unproductive lands they owned with the lucrative spineless Opuntia crop and land developers joined in, parceling land with the promise of riches for property owners who planted the miracle crop (Smith, 2010). Demand for spineless Opuntia continued to climb, yet the Thornless Cactus Farming Company was not meeting payment deadlines for Burbank. Seeking to boost sales, Burbank continued promoting himself (Fig. $31 \mathrm{C}$ ) and the cacti through a litany of mass media outlets, speaking engagements, and biographical works (Smith, 2010). In 1913, the Luther Burbank Company formed, to consolidate controlling interests and marketing of all of Burbank's plant introductions, including the spineless Opuntia for $\$ 30,000$ (Smith, 2010). Bad business decisions doomed both the Thornless Cactus Farming Company and later the Luther Burbank Company, both of whom focused on marketing, selling shares, and taking orders, but not production. To meet demand, the Luther Burbank Company removed the spines from wild-type Opuntia and sold them off as the Burbank's spineless introductions, the fraud ultimately leading to bankruptcy in 1916 (Smith, 2010).

\section{THE BURBANK LEGACY: FINAL SYNOPSIS}

"What makes Burbank's work entirely different from that of other plant breeders is the immense scale on which his selecting is made...in his work, Burbank is guided by a special gift of judgment" (De Vries, 1905). Indeed, he was excellent at mass selection (pollen roulette) with a keen eye for selection and produced an array of beauty with wide adaptability, although there were only tested in one to two locations (Santa Rosa and Sebastopol, CA). His "rush to market" products were often fraught with disasters leading to bankruptcies. Although most of Burbank's ornamental cultivars have been lost, their numerous descendants have forever sealed Luther's reputation as the Father of American Ornamental Breeding, admirably from critics and devotees alike.

Throughout the past century, multiple ornamental plant breeders and public/private 

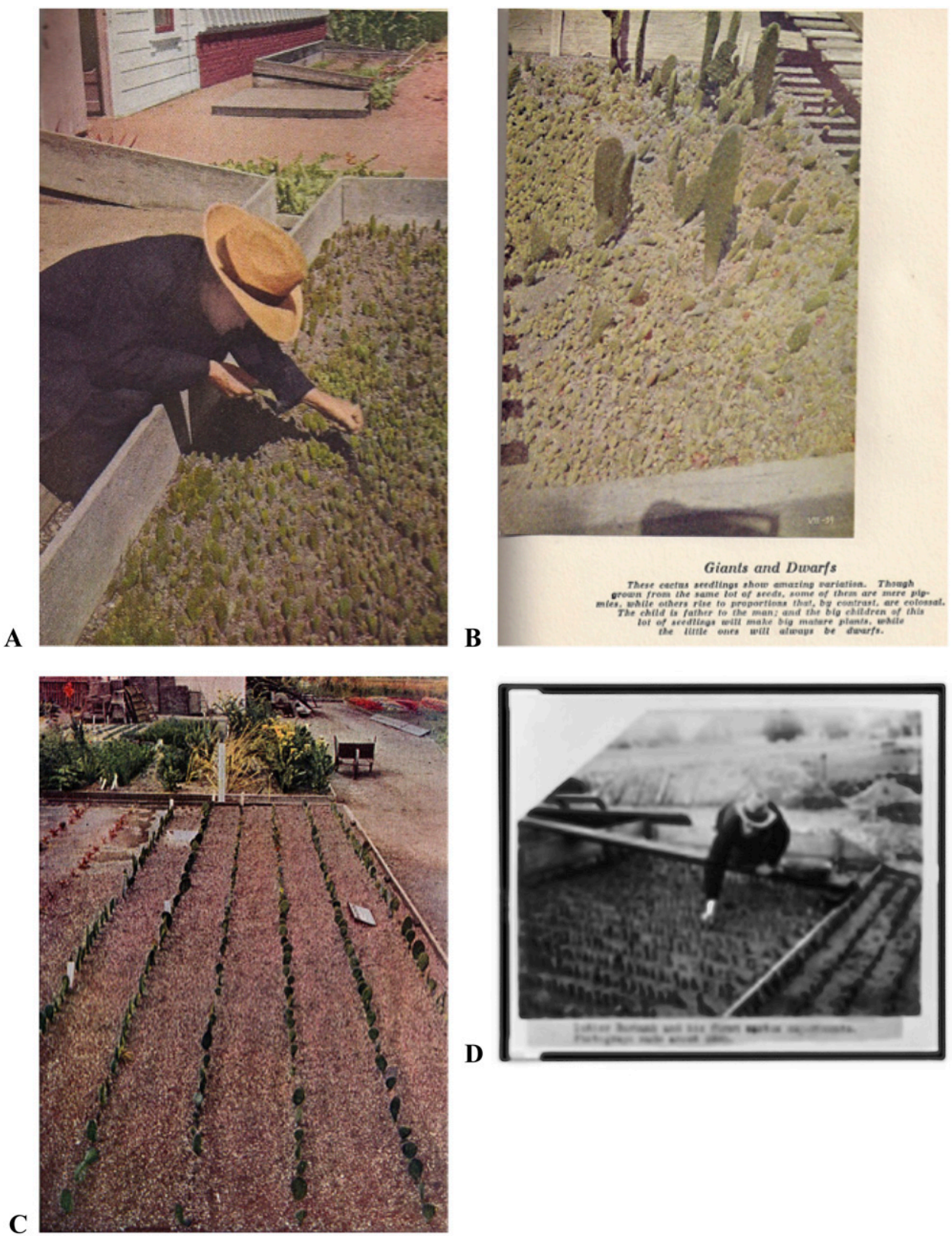

Fig. 34. Cactus selection procedures for "yield potential": (A) a broadcast-sown outdoor coldframe for selecting segregating and heterotic seedlings ready for transplanting (Stage IV); (B) a non-selected flat left to grow out; (C) rouging and selection of large beds of transplants involved precarious balancing on wooden planks placed above the frames, and (D) rows of transplanted seedlings and pad propagation after initial selections (Burbank, 1914-15).

programs have used many, if not all, of Burbank's techniques albeit along with his mistakes. Secrecy continues to pervade breeding programs because market value is derived from process, germplasm ownership of inbred parents for hybrid seed production, etc. Only in instances of scientific or popular press publications, U.S. Plant/Utility Patents, and Plant Breeders' Rights (in the rest of the world) is pedigree information ever revealed to the public domain. Otherwise, the proprietary breeding records and germplasm (carefully preserved in vaults for orthodox seed or clonal stock plant repositories) remain unknown and continue the mystique of flower breeders.

Modern-day marketers, salespersons, breeders, distributors, and retailers alike would do well to reread Burbank's accomplishments lest they unknowingly resurrect taxa such as
Osteospermum, trailing (wave ${ }^{\mathrm{TM}}$ ) Petunia, red Iris, or white or crimson Eschscholtzia as "new crops." As history continues to demonstrate, 50 to 100 years after crops disappeared from market favor, they are "rediscovered" anew. Our richness of ornamental products is the direct result of modern-day breeders working contextually within the wealth of science and the undiscovered germplasm bank of previous breeders such as Luther Burbank.

\section{Literature Cited}

Allard, R.W. 1960. Principles of plant breeding. John Wiley and Sons, New York, NY.

Anderson, N.O. (ed.). 2006. Flower breeding \& genetics: Issues, challenges, and opportunities for the 21 st century. Springer, Dordrecht, The Netherlands.
Anderson, N.O., S.M. Galatowitsch, and N. Gomez. 2006a. Selection strategies to reduce invasive potential in introduced plants. In: Anderson, N.O. and S.M. Galatowitsch (eds.). Plant breeding and crop domestication as sources of new invasive species. Euphytica 148:203-216.

Anderson, N.O., N. Gomez, and S.M. Galatowitsch. 2006b. A non-invasive crop ideotype to reduce invasive potential. In: Anderson, N.O. and S.M. Galatowitsch (eds.). Plant breeding and crop domestication as sources of new invasive species. Euphytica 148:185-202.

Anderson, N.O., A. Younis, and Y. Sunday. 2010. Intersimple sequence repeats distinguish genetic differences in Easter lily 'Nellie White' clonal ramets within and among bulb growers over years. J. Amer. Soc. Hort. Sci. 135:445-455.

Beaty, J.Y. 1954. Luther Burbank, plant magician. Messner Pub. Co., Winter Haven, FL.

Benson, L. 1982. The uses of cacti, p. 216-241. In: Benson, L. (ed.). The cacti of the United States 
and Canada. Stanford Univ. Press, Stanford, CA.

Burbank, L. 1893. New creations in fruits and flowers. Santa Rosa, CA.

Burbank, L. 1894. Special trade list. Novelties not before offered. Oct. 1894. Santa Rosa, CA.

Burbank, L. 1899. New creations in fruits and flowers. Santa Rosa, CA.

Burbank, L. 1904. The new Shasta daisies 'Alaska', 'California', 'Westralia'. Santa Rosa, CA.

Burbank, L. 1907. The new agricultural-horticultural Opuntias: Plant creations for arid regions. Santa Rosa, CA.

Burbank, L. 1909. A brief descriptive list of the New Burbank Giant Amaryllis. Santa Rosa, CA.

Burbank, L. 1911. Burbank's twentieth century gladiolus, offered for the first time with other new and rare bulbs, mostly unobtainable elsewhere, 1911-1912. To judge novelties...look to their source. Santa Rosa, CA.

Burbank, L. 1914-15. Luther Burbank, his methods and discoveries and their practical application. Prepared from his original field notes covering more than 100,000 experiments made during forty years devoted to plant improvement. In: Williams, H.S., R.J. Whitson, and J. Whitson (eds.). Luther Burbank Press, New York, NY.

Burbank, L. 1915a. Burbank price and descriptive catalog. Plants, seeds, and trees. Season 19151916. Santa Rosa, CA.

Burbank, L. 1915b. Luther Burbank creationsbulletin of new productions-season 1915. Santa Rosa, CA.

Burbank, L. 1917. Burbank's bulb catalog and how to judge novelties. Santa Rosa, CA.

Burbank, L. 1918a. Burbank's 1918 new creations and special new selections in seeds. Santa Rosa, CA.

Burbank, L. 1918b. Burbank's 1918 offering of twentieth century fruits, flowers and various economic plants. Santa Rosa, CA.

Burbank, L. 1919. Burbank's new creations and special new selections in seeds. Santa Rosa, CA.

Burbank, L. 1920a. Burbank's 1920 new creations and special new selections in seeds. Santa Rosa, CA.

Burbank, L. 1920b. Burbank's 1920 offering of twentieth century fruits, flowers and various economic plants. Santa Rosa, CA.

Burbank, L. 1925. Burbank's offering of economic and ornamental plants. Bulletin No. 69. Santa Rosa, CA.

Bush, L. 1982. Luther Burbank. Pacific Hort. 43:3-9.

Crow, J.F. 2001. Plant breeding giants: Burbank, the artist; Vavilov, the scientist. p. 1391-1395. In: Crow, J.F. and W.F. Dove (eds.). Anecdotal, historical and critical commentaries on genetics. Genetics Society of America.

Darwin, C.R. 1868. Variation of animals and plants under domestication. John Murray, UK.

De Vries, H. 1905. A visit to Luther Burbank. Popular Science Monthly 67:329-347.

De Vries, H. 1907. Plant breeding: Comments on the experiments of Nilsson and Burbank. Open Court Publishing, Chicago, IL.

Drew, J., N.O. Anderson, and D. Andow. 2010. Conundrums of a complex vector for invasive species: A detailed examination of the horticultural industry. Biol. Invasions 12:2837-2851.

Dreyer, P. 1993. A gardener touched with genius: The life of Luther Burbank. 2nd Ed. Luther Burbank Home and Gardens, Santa Rosa, CA.

Griffith, M.P. 2004. The origins of an important cactus crop, Opuntia ficus-indica (Cactaceae): New molecular evidence. Amer. J. Bot. 91:1915-1921.

Griffiths, D. 1905. The prickly pear and other cacti as food for stock. USDA Bur. Plant Ind. Bul. 74.

Griffiths, D. 1912. The thornless prickly pears. USDA Farmer's Bul. 483.

Griffiths, D. 1913. Behavior under cultural conditions of species of cacti known as Opuntia. USDA Bul. 31.

Griffiths, D. 1928. Prickly pear as stock feed. USDA Farmer's Bul. 1072.

Hall, W. (ed.). 1939. Partner of nature by Luther Burbank. D. Appleton-Century, New York, NY.

Hatch, L.C. 2013. Leucanthemum Maximum Group. Hatch's perennials 3.0., New Ornamentals Society. 30 Jan. $2014<$ http://members. tripod.com $/ \sim$ Hatch_L/cvleucopen.pdf $>$.

Hawke, R.G. 2007. A report on Leucanthemum $\times$ superbum and related daisies. Plant Evaluation Notes, Issue 30, Chicago Botanic Garden, Chicago, IL. 30 Jan. $2014<$ https://www chicagobotanic.org/downloads/planteval_notes/ no30_leucanthemum.pdf $>$.

Hickman, J.C. (ed.). 1993. The Jepson manual: Higher plants of California. Univ. of California Press, Berkeley, CA.

Hogenboom, N.G. 1974. Incompatibility and incongruity in intimate partner relationships. Agricultural Research Report, Netherlands Centre for Agricultural Publishing and Documentation. No. 804.

Hornback, R. 1982. Shasta daisies. Pacific Hort. 43:3-8.

Howard, W.L. 1945. Luther Burbank's plant contributions. University of California, College of Agriculture, Agricultural Experiment Station, Bulletin 691. Berkeley, CA.

Hunter, N. 2012. The art of floral design. Cengage Learning, Independence, KY.

Ingram, J. 1975. Nonmenclatural notes for Hortus Third. Baileya 19:163-171.
Kelly, H., Jr. 1983. The origin of Crinum $\times$ clone 'White Queen' (Burbank-Henderson, 1930). Plant Life 39:66-77.

Kent, D.H. 1990. The shasta daisy. Watsonia 18:89.

Konjoian, P. 1999. Containers, p. 9-12. In: Buck, C.A., S.A. Carver, M.L. Gaston, P.S. Konjoian, L.A. Kunkle, and M.F. Wilt (eds.). Tips on growing bedding plants. $4^{\text {th }}$ Ed. Ohio Florists' Association, Columbus, $\mathrm{OH}$.

Martinez, R.A. 1992. The master of seeds-Life and work of Claude Hope. Burpee Books, Warminster, PA.

McDonald, M. 1999. Seed quality and germination, p. 13-23. In: Buck, C.A., S.A. Carver, M.L. Gaston, P.S. Konjoian, L.A. Kunkle, and M.F. Wilt (eds.). Tips on growing bedding plants. 4th Ed. Ohio Florists' Association, Columbus, $\mathrm{OH}$.

McWhorter, F.P. 1937. A latent virus of lily. Science 86:179.

Meckenstock, D.H. 2005. Breeding red irises: The carotenoids. Instant Publisher.com, Daniel Meckenstock, Hays, KS. 163 pp.

PanAmerican Seed Company. 1999. Product information guide. PanAmerican Seed Company, W. Chicago, IL.

Pollan, M. 2001. Claude Hope: Floral conquest. The New York Times Magazine, Jan. 7 issue.

Purdy, C. 1895. Luther Burbank's hybrid lilies. Garden and Forest 8:328-329.

Russell, C.E. and P. Felker. 1987. The pricklypears (Opuntia spp., Cactaceae): A source of human and animal food in semiarid regions. Econ. Bot. 41:433-445.

Slate, G.L. 1939. Lilies for American gardens. Charles Scribner's Sons, New York, NY.

Smith, J.S. 2009. The garden of invention: Luther Burbank and the business of breeding plants. Penguin Books, London, UK.

Smith, J.S. 2010. Luther Burbank's spineless cactus: Boom times in the California desert. Calif. Hist. (San Francisco) 87:26-47, 66-68.

Takii Seed Company. 2014. Stock: Cinderella ${ }^{\mathrm{TM}}$ series. Takii Seed Co., Kyoto, Japan. 5 Feb. 2014. <http:// www.takiiseed.com/goods_list/goods_list_7. php? $=3 \&$ called $=$ hijbwsrsok \& sort $=$ code $\&$ disp $=10 \&$ now_page $=3 \& \mathrm{~m} \_$no $=$Cinderella $>$.

Williams, H.S. (ed.). 1915. Burbank, his life and works (12 vol.). Heart's International Library Co., New York, NY.

Zlesak, D. and N.O. Anderson. 2007. Clonal variability among grower bulb lots of Easter lily 'Nellie White'. J. Amer. Soc. Hort. Sci. 132:29-43.

Zlesak, D., J. Bradeen, and N.O. Anderson. 2007. The use of AFLP markers to resolve clonal origin and integrity in rose, hydrangea, and lily. Floriculture and Ornamental Biotechnology 1:51-60. 